Poznańskie Studia Teologiczne 30(2016), s. 251-284.

doi: $10.14746 /$ pst.2016.30.13

\author{
Zbigniew Kubacki ${ }^{1}$ \\ Papieski Wydział Teologiczny w Warszawie - Collegium Bobolanum
}

\title{
Ekskluzywizm ewangelikalny
}

W chrześcijańskiej teologii religii wyszczególnia się zasadniczo trzy podstawowe paradygmaty: ekskluzywizm, inkluzywizm i pluralizm. Pluralizm traktuje wszystkie religie jako równouprawnione drogi prowadzące do Boga rozumianego jako Ostateczna Rzeczywistość sama w sobie niepoznawalna. Ponadto zwolennicy tego paradygmatu negują bóstwo Jezusa Chrystusa i w konsekwencji prawdę o Jego jedyności i powszechności zbawczej. Najwybitniejszym przedstawicielem tego nurtu jest anglikański filozof i teolog John Hick. I n k 1 u z y w i z m zdecydowanie staje w obronie bóstwa oraz jedyności i powszechności zbawczej Jezusa Chrystusa. Niemniej jednak, jego zwolennicy uznają, że ci, którzy - jako wyznawcy religii niechrześcijańskich czy osoby niereligijne - jeszcze nie przyjęli Ewangelii, mogą być dotknięci Bożą łaską, na nią pozytywnie opowiedzieć i osiaggnąc zbawienie. Zdecydowana większość teologów chrześcijańskich utożsamia się z tą opcją. Jest to również oficjalne stanowisko Kościoła katolickiego. Ekskluzywizm także wyznaje jedyność i powszechność zbawczą Jezusa Chrystusa. Dlatego twierdzi, że ci, którzy żyli przed przyjściem Chrystusa, mogli osiagnąć zbawienie, jeśli pozytywnie odpowiedzieli na specjalnie objawienie, a ci, którzy żyją po Jego przyjściu, aby osiągnać zbawienie muszą w sposób explicite wyznać wiarę w Jezusa Chrystusa jako Pana i Zbawiciela. We współczesnym chrześcijaństwie najwięcej zwolenników tej opcji znajduje się pośród teologów ewangelikalnych. Z nurtem ewangelikalnym utożsamiają się chrześcijanie różnych wyznań protestanckich. Charakteryzuje ich, po pierwsze, wiara w konieczność nawrócenia określanego często jako „powtórne narodzenie” (born-again); po drugie - autorytet Biblii, czyli że całe nauczanie Kościoła winno być wprost wyprowadzone z Pisma Świętego; po trzecie - silny akcent położony na ofiarę Jezusa Chrystusa na Krzyżu jako ofiarę zadośćuczynienia i odkupienia całej ludzkości; po czwarte - duch misyjny. Radykalnie odcinają się oni od liberalnych nurtów teologii protestanckiej, które -

\footnotetext{
${ }^{1}$ Zbigniew Kubacki SJ - jezuita. Rektor Collegium Bobolanum i prorektor Papieskiego Wydziału Teologicznego w Warszawie. Wykłada teologię dogmatyczną i teologię religii. Ostatnio opublikował książkę Kościót, religie i zbawienie (Kraków 2016).
} 
ich zdaniem - zakwestionował wiarę w bóstwo Jezusa oraz Jego jedyność i powszechność zbawczą.

Jeśli z jednej strony teologowie ewangelikalni opcji ekskluzywistycznej wierzą, że dzieci, które umierają w niemowlęctwie oraz osoby $\mathrm{z}$ niepełnosprawnością intelektualną zostaną zbawione ${ }^{2}$, tak z drugiej strony jednoznacznie stwierdzają, że po śmierci i zmartwychwstaniu Jezusa do zbawienia jest konieczna wiara o charakterze explicite w Jezusa Chrystusa ${ }^{3}$. Jakie podają uzasadnienie tego przeświadczenia?

\section{O zbawczym losie dzieci, które umierają w niemowlęctwie, oraz osób $\mathrm{z}$ niepelnosprawnością intelektualną chorych}

Pierwszym, często przywoływanym argumentem na rzecz zbawienia dzieci, które umierają $\mathrm{w}$ wieku niemowlęcym, jest argument ex auctoritate, czyli zdanie z Westminsterskiego Wyznania Wiary (1646): „Wybrane dzieci, umierające w niemowlęctwie, dostępują odrodzenia i zbawienia w Chrystusie przez Ducha Świętego, który działa w tym czasie, miejscu i w taki sposób, jak Mu się to podoba. To samo dotyczy wszystkich wybranych osób, które nie są zdolne do zewnętrznego powołania przez zwiastowanie Ewangelii” (10, 3) $)^{4}$. Zauważmy, że w cytowanym zdaniu mowa jest o ,wybranych dzieciach”. Jest to podejście charakterystyczne dla teologii kalwińskiej reformowanej, w której bardzo silnie akcentowana jest predestynacja do zbawienia: Bóg przychodzi ze swoją łaską i zbawia jedynie ludzi do tego przeznaczonych. Teoretycznie można jednak przyjąć, że wszystkie rodzące się dzieci są przez Boga wybrane i predestynowane. Argument teologiczny, jaki jest w tym cytacie zawarty, to: odrodzenie i zbawienie tych dzieci w Chrystusie przez Ducha Świętego, który działa w czasie, miejscu i w taki sposób, jak Mu się to podoba.

W teologii katolickiej bardzo podobny argument znajdujemy w nauczaniu Soboru Watykańskiego II w Konstytucji duszpasterskiej o Kościele w świecie współczesnym. Czytamy tam, że „Duch Święty wszystkim ofiaruje możliwość dojścia w sposób Bogu wiadomy do uczestnictwa w tej [Chrystusa] paschalnej

${ }^{2}$ Zob. np. R.H. Nash, When a Baby Dies. Answers to Confort grieving Parents, Michigan 1999; tenże, Restrictivism, w: What About Those Who Have Never Heard? Three Views on the Destiniy of the Unevangelized, red. J. Sanders, Downers Grove [USA, Illinois] 1995, s. 118-120; Ch.W. Morgan, R.A. Peterson, Answers to Notable Questions, w: Faith Comes by Hearing. A Response to Inclusivisme, red. Ch.W. Morgan, R.A. Peterson, Downers Grove [USA, Illinois] 2008, s. 244.

${ }^{3}$ Zob. np. R.H. Nash, Restrictivism, dz. cyt., s. 116; Ch.W. Morgan, R.A. Peterson, Answers to Notable Questions, dz. cyt., s. 249.

${ }^{4}$ Westminsterskie Wyznanie Wiary, http://www.gdansk.reformacja.pl/2012-04-13-08-46-32/ 2012-04-13-08-46-53/30-westminsterskie-wyznanie-wiary-cz1.html [dostęp: 01.09.2016]. Zdanie to cytowane jest np. w: R.H. Nash, Restrictivism, dz. cyt., s. 119. 
tajemnicy"5. Różnica jest jednak zasadnicza. Podczas gdy w Westminsterskim Wyznaniu Wiary i odwołującej się do niego ekskluzywistycznej teologii ewangelikalnej zbawcze działanie Duch Świętego dotyczy jedynie niemowląt oraz osób z niepełnosprawnością intelektualną, tak w nauczaniu Soboru Watykańskiego II odnosi się ono do „wszystkich ludzi dobrej woli”.

Ronald H. Nash, jeden z czołowych teologów ewangelikalych, w następujący sposób uzasadnia stanowisko ekskluzywistyczne. Zauważa, że na podstawie nauczania Pisma Świętego (zwłaszcza Listu do Rzymian), po pierwsze, należy uznać, że w Adamie wszyscy ludzie (także niemowlęta oraz osoby z niepełnosprawnością intelektualna) zgrzeszyli i są przedmiotem Bożego gniewu, i nikt (również oni) nie może rościć sobie przed Bogiem prawa do zbawienia. Jak wiemy, na podstawie tego argumentu św. Augustyn skazywał wszystkich niechrzczonych, także niemowlęta, na karę piekła: massa damnata. Teolodzy ewangelikalni choć uznają, że zgodnie z Rz 5,18 „w grzechu Adama wszyscy jesteśmy potępieni" ", w swojej ocenie losu dzieci, które umierają w niemowlęctwie, nie idą jednak za biskupem Hippony. Nie podążają też ścieżką wyznaczoną przez teologów średniowiecza i zaakceptowaną przez wieki w nauczaniu Magisterium Kościoła katolickiego, mianowicie ścieżką doktryny o limbus puerorum: miejscu na obrzeżach piekła, gdzie nie ma cierpienia, a nawet jest pewien rodzaj szczęśliwości naturalnej; ale nie jest to wizja uszczęśliwiająca świętych w niebie. Przeciwnie, dzieciom, które umierają w niemowlęctwie (oraz osobom z niepełnosprawnością intelektualna), teologowie ewangelikalni otwierają bramy nieba. Co prawda zauważają, że na podstawie Rz 5,14 („A przecież śmierć rozpanoszyła się od Adama do Mojżesza nawet nad tymi, którzy nie zgrzeszyli przestępstwem na wzór Adama") można by wnioskować, iż także one zostaną potępione, niemniej jednak - zauważają - „nie jest to oczywiste, że będą ostatecznie skazane, ponieważ nie popełniły żadnego osobistego grzechu, który stanowi podstawę skazania wymierzonego w dniu sądu nad nie-wybranymi"». Na podstawie nauczania Biblii teolodzy ewangelikalni argumentują dalej, że w Piśmie Świętym potępienie nie jest wynikiem samej solidarności z grzechem Adama, lecz jest skutkiem grzechów osobistych. Natomiast dzieci (oraz osoby z niepełnosprawnością intelektualną) takich grzechów nie popełniły, ponieważ umarły przed czasem świadomego posługiwania się rozumem. Stwierdzają zatem, że z racji ich solidarności z grzechem Adama (grzech pierworodny) co prawda spada na nie potępienie właściwe Adamowi, ale jednocześnie „bez osobistego aktu wiary za-

\footnotetext{
${ }^{5}$ Sobór Watykański II, Konstytucja duszpasterska o Kościele w świecie współczesnym Gaudium et spes, w: Sobór Watykański II. Konstytucje, Dekrety, Deklaracje. Tekst łacińsko-polski, Paris $1967, \mathrm{nr} 22$.

${ }^{6}$ Tamże

${ }^{7}$ Ch.W. Morgan, R.A. Peterson, Answers to Notable Questions, dz. cyt., s. 241.

${ }^{8}$ R.H. Nash, Restrictivism, dz. cyt., s. 119.
} 
szczepione są w zbawcze dobrodziejstwa dzieła Chrystusa. [...] Oczywiste jest, że dzieci potrzebują bycia odrodzonymi, ale nie jest to określone, kiedy: każdy czas między byciem w łonie matki a czasem ich śmierci wydaje się możliwy"9. Zasadniczy argument teologiczny w swoim wywodzie Nash przejmuje od innego teologa ewangelikalnego, Roberta A. Webba ${ }^{10}$. Nash pisze:

Zdaniem R. A. Webba, gdyby zmarłe dziecko „było skazane na piekło jedynie z racji grzechu pierworodnego, dla Bożego umysłu byłby to wystarczający powód dla sądu, ale w umyśle dziecka byłaby całkowita pustka jeśli chodzi o rację jego cierpienia. $\mathrm{W}$ takich okolicznościach, znałoby ono cierpienie, ale nie miałoby zrozumienia powodów tego cierpienia. Nie mogłoby powiedzieć swemu bliźniemu - nie mogłoby powiedzieć sobie samemu - dlaczego tak strasznie zostało dotknięte; w konsekwencji cały sens i znaczenie jego cierpień [...], cała istota kary byłaby nieobecna, a sprawiedliwość byłaby rozczarowana swoją odpłatą". W konsekwencji, Webb stwierdza, że nieodrodzone dziecko (unregenerate infant) ,nie może umrzeć w swoim dzieciństwie: coś takiego byłoby klęską celów [Bożej] sprawiedliwości. W konsekwencji .... wszystkie dzieci umierając w dzieciństwie są wybrane, odkupione, odrodzone i uwielbione. ... Śmierć małego dziecka jest zatem dowodem [nie do odrzucenia] jego zbawienia" 11 .

Jak widzimy, centralny argument odwołuje się do Bożej sprawiedliwości. Wypowiedź Webba (i Nasha, który ją akceptuje) można by sparafrazować w taki oto sposób: Owszem, wszyscy dotknięci są grzechem pierworodnym, także małe dzieci (oraz osoby $\mathrm{z}$ niepełnosprawnością intelektualna). $\mathrm{Z}$ tego powodu Bóg mógłby skazać je na wieczne potępienie. Jednak, czyniąc to, Bóg nie osiagnąłby celów swojej sprawiedliwości. Celem bowiem Bożej sprawiedliwości jest, aby osoba skazana na potępienie rozumiała, dlaczego otrzymała taką karę. W przypadku osoby dorosłej jest to oczywiste. Tak nie jest w przypadku małego dziecka. Ono bowiem - z racji niezdolności do używania rozumu - nie pojęłoby, dlaczego taka kara je spotyka. Zatem, takie dziecko, które umiera w młodym wieku, jest - przed śmiercią - przez Chrystusa, mocą Ducha Świętego, wybrane, odkupione, odrodzone i uwielbione.

Zestawiając to nauczanie teologów ewangelikalnych z nauczaniem Kościoła katolickiego zawartym w dokumencie Międzynarodowej Komisji Teologicznej pt. Nadzieja zbawienia dla dzieci, które zmarty bez chrztu (2007) ${ }^{12}$, stwierdzić należy, że istnieje między nimi duże podobieństwo. Watykański dokument otwiera perspektywę nadziei, „iż dzieci zmarłe bez chrztu mogą być zbawione i wprowadzone do wiecznego szczęścia, choć na ten temat nie ma wyraźnego naucza-

\footnotetext{
${ }^{9}$ R.H. Nash, Restrictivism, dz. cyt., s. 120.

${ }^{10}$ R.A. Webb, The Theology of Infant Salvation, Richmond [USA, Virginia] 1907.

${ }^{11}$ R.H. Nash, When a Baby Dies, dz. cyt., s. 64.

${ }^{12}$ Międzynarodowa Komisja Teologiczna, Nadzieja zbawienia dla dzieci zmarlych bez chrztu. Dokument watykański, Radom 2008.
} 
nia Objawienia"13. W epoce Nowego Testamentu kwestia chrztu odnosiła się bowiem zasadniczo do osób dorosłych i pytanie o możliwość czy jej brak uzyskania zbawienia Bożego dla noworodków lub dzieci zmarłych bez chrztu nie było zasadniczo podejmowane. Niemniej jednak w Nowym Testamencie można znaleźć fundamentalne pouczenia biblijne do odpowiedzi na to pytanie. Autorzy dokumentu wymieniają pięć z nich, które warto zacytować w całości:

I. Boża wola zbawienia człowieka (patrz $1 \mathrm{Tm}$ 2,3-6) przez zwycięstwo Jezusa Chrystusa nad grzechem i śmiercią (Ef 1,20-22; Flp 2,7-11; Rz 14,9; 1 Kor 15,20-28).

II. Powszechna grzeszność ludzi, którzy z tego względu są przeznaczeni na śmierć (patrz Rz 5,12; 1 Kor 15,22).

III. Konieczność, dla zbawienia, z jednej strony wiary wierzącego (patrz Rz 1,16), a z drugiej chrztu (patrz Mk 16,16; Mt 28,19; Dz 2,40-4) i Eucharystii (patrz J 6,53), udzielanych przez Kościół.

IV. Nadzieja chrześcijańska mówi, że żywy Bóg, Zbawiciel ludzkości (patrz 1 Tm 4,10 ), wszystkich uczyni uczestnikami swojej chwały i że wszyscy będą żyć z Chrystusem (patrz 1 Tes 5,9-11; Rz 8,2-5. 23-25), oraz że chrześcijanie muszą być gotowi uzasadnić swoją nadzieję (patrz 1 P 3,15).

V. Kościół powinien zanosić „,prośby, modlitwy i dziękczynienia za wszystkich ludzi” (1 Tm 2,1-8), wierząc, że dla stwórczej mocy Boga „nie ma nic niemożliwego” (Hi 42,2; Mk 10,27; 12,24.27; Łk 1,37) i w nadziei, że całe stworzenie będzie uczestniczyć w końcu w chwale Bożej (patrz Rz 8,22-27) ${ }^{14}$.

W dalszej części dokumentu teologowie Międzynarodowej Komisji Teologicznej zwracają uwagę na istniejące w tekstach biblijnych napięcie między dwiema prawdami: „Z jednej strony powszechna wola zbawcza Boga, a z drugiej konieczność chrztu sakramentalnego" ${ }^{15}$. Wskazane także są trzy stałe i niezmienne zasady doktrynalne:

I) Bóg chce, aby wszyscy ludzie byli zbawieni.

II) Zbawienie to jest dane tylko za pośrednictwem uczestniczenia w tajemnicy paschalnej Chrystusa, czyli za pośrednictwem chrztu na odpuszczenie grzechów, czy to sakramentalnego, czy mającego inną formę. Ludzie, w tym również dzieci, nie mogą być zbawieni w oderwaniu od łaski Bożej rozlewanej przez Ducha Świętego.

III) Dzieci nie wejdą do Królestwa Bożego, jeżeli nie zostały uwolnione od grzechu pierworodnego przez łaskę odkupieńczą ${ }^{16}$.

W porównaniu z teologią wieków przeszłych dokument dowartościowuje biblijne nauczanie o powszechnej woli zbawczej Boga dobitnie wyrażone w Pierwszym Liście do Tymoteusza (1 Tm 2,3-6). Autorzy podkreślaja, że tajemnica tej woli ,korzeniami sięga planu Ojca, aby swego Syna uczynić nie tyl-

\footnotetext{
${ }^{13}$ Tamże, s. 6.

${ }^{14}$ Tamże, nr 9.

${ }^{15}$ Tamże, nr 10.

16 Tamże, nr 32.
} 
ko «Pierworodnym między wielu braćmi» (Rz 8,29), ale także «Pierworodnym wobec każdego stworzenia [...] Pierworodnym spośród umarłych» (Kol 1,15.18)"'17. Przywołany tu chrystologiczny hymn z Listu do Kolosan najwyraźniej pokazuje, że powszechna wola zbawcza Boga zakorzeniona jest w odwiecznym stwórczym i zbawczym planie Trójcy Świętej. Tego fundamentalnego odniesienia zasadniczo brakuje $\mathrm{w}$ argumentacji teologów ewangelikalnych opcji ekskluzywistycznej. Powrócimy do tego w dalszej części artykułu. Teologowie ewangelikalni natomiast podkreślają (i słusznie) prawdę o jedyności i powszechności zbawczej Jezusa Chrystusa. W Nowym Testamencie zasada ta wyrażona jest chociażby w słowach: „Nie ma w żadnym innym zbawienia, gdyż nie dano ludziom pod niebem żadnego innego imienia, w którym moglibyśmy być zbawieni" (Dz 4,12). Autorzy watykańskiego dokumentu potwierdzają to nauczanie, zauważając, że jest ono obecne zarówno w nauczaniu Tradycji, jak i najnowszego Magisterium Kościoła.

Trzecia prawda wiary, którą przypomina watykański dokument, a którą znajdujemy także u teologów ewangelikalnych, dotyczy powszechności grzechu i powszechnej konieczności zbawienia. Najważniejsze jest tu nauczanie św. Pawła w Liście do Rzymian, dla którego powszechność odkupienia dokonanego przez Jezusa Chrystusa znajduje swój odpowiednik w powszechności grzechu. „Ta solidarność z pierwszym człowiekiem, Adamem, jest przedstawiona w dwóch tekstach Pawłowych: 1 Kor 15,21, a zwłaszcza Rz 5,12""18.

W uzasadnieniu teologicznym nadziei zbawienia dla dzieci, które umieraja bez chrztu, przywołany jest słynny passus z konstytucji Gaudium et spes 22: „Skoro bowiem Chrystus umarł za wszystkich i skoro ostateczne powołanie człowieka jest w istocie jedno, mianowicie Boskie, powinniśmy utrzymywać, że Duch Święty wszystkim daje możliwość uczestniczenia w tym misterium paschalnym w tylko Bogu znany sposób" ${ }^{19}$. W kontekście dokumentu watykańskiego słowo „wszystkich” odniesione jest w sposób szczególny do dzieci, które umierają bez chrztu, choć w tekście konstytucji odnosi się ono do wszystkich ludzi w ogóle. W dalszej części dokument Międzynarodowej Komisji Teologicznej przedstawia argumentację biblijno-teologiczną. Najważniejszy argument opiera się na fundamentalnej jedności i solidarności Chrystusa z każdym człowiekiem, a więc także z każdym poczętym dzieckiem. Uzasadnieniem biblijnym jest tu przede wszystkim tekst z Listu do Kolosan, gdzie czytamy m.in.:

On jest obrazem Boga niewidzialnego, Pierworodnym wobec każdego stworzenia, bo w Nim zostało wszystko stworzone: i to, co w niebiosach, i to, co na ziemi, byty widzialne i niewidzialne [...]. Wszystko przez Niego i dla Niego zostało stworzone.

${ }^{17}$ R.H. Nash, Restrictivism, dz. cyt., nr 47.

${ }^{18}$ Tamże, nr 54.

${ }^{19}$ Sobór Watykański II, Konstytucja duszpasterska o Kościele w świecie współczesnym Gaudium et spes, dz. cyt., $\mathrm{nr} 22$. 
On jest przed wszystkim i wszystko w Nim ma istnienie. I On jest Głową Ciała Kościoła. On jest Początkiem, Pierworodnym spośród umarłych, aby sam zyskał pierwszeństwo we wszystkim (Kol 1,15-18).

Tego zasadniczego odniesienia biblijnego brakuje w argumentacji teologii ewangelikalnej.

Kolejnym istotnym uzasadnieniem teologicznym jest nauczanie soboru na temat tajemnicy wcielenia. W konstytucji Gaudium et spes czytamy: „Albowiem On, Syn Boży, przez swoje wcielenie zjednoczył się w pewien sposób z każdym człowiekiem"20. Komentując ten fragment, teologowie watykańskiej komisji piszą: „Zatem nie ma nikogo, kogo nie dotykałaby tajemnica Słowa, które stało się Ciałem”21. I w innym miejscu: „Pragniemy podkreślić, że solidarność ludzkości z Chrystusem (albo ściślej: solidarność Chrystusa z ludzkością) musi mieć priorytet nad solidarnością z Adamem, i to w takim ujęciu powinno się podejmować temat losu dzieci zmarłych bez chrztu"22. W teologii tradycyjnej, wewnątrz której zrodziła się teoria Augustyna o massa damnata czy średniowieczna teoria o limbus puerorum, ludzkość pojmowano przede wszystkim w perspektywie solidarności z Adamem jako pierwotnej i podstawowej. To, co proponuje dokument watykański, to jest przywrócenie solidarności z Chrystusem (a ściślej: Chrystusa z nami) jako jeszcze bardziej pierwotnej i bardziej podstawowej. Tego właśnie, naszym zdaniem, brakuje w teologicznym uzasadnieniu teologów ewangelikalnych opcji ekskluzywistycznej, a co stanowi biblijno-teologiczny fundament na rzecz nadziei zbawienia dla dzieci, które umierają bez chrztu.

Przy omawianiu interesującego nas zagadnienia watykański dokument odwołuje się także do zmysłu wiary (sensus fidei) Ludu Bożego, wyrażonego w liturgicznej modlitwie Kościoła. W argumentacji teologii ewangelikalnej tego zupełnie nie ma. Ich zdaniem, argumentacja winna wypływać jedynie z Pisma Świętego zgodnie z protestancką zasadą sola Scriptura. Dokument watykański przedstawia to następująco: „Modlitwa liturgiczna odzwierciedla, a jednocześnie nadaje formę sensus fidei Kościoła łacińskiego w odniesieniu do losu dzieci zmarłych bez chrztu: lex orandi, lex credendi" ${ }^{23}$. W kolejnym zdaniu przedstawiona jest wizja greckiego Kościoła prawosławnego, dla którego także liturgia jest locus theologicus rzucającym dodatkowe światło nadziei, na które my, katolicy, również powinniśmy być otwarci. Czytamy w nim: „Znaczące jest to, że w greckim Kościele prawosławnym przewiduje się takie same obrzędy pogrzebowe dla dzieci ochrzczonych i nieochrzczonych, a Kościół modli się za wszystkie zmarłe dzieci, ażeby mogły być przyjęte na łono Abrahama, gdzie nie ma już cierpienia czy

${ }^{20}$ Tamże, $\mathrm{nr} 22$.

${ }^{21}$ Międzynarodowa Komisja Teologiczna, Nadzieja zbawienia dla dzieci zmartych bez chrztu, dz. cyt., nr 89.

${ }^{22}$ Tamże, nr 91.

${ }^{23}$ Tamże, nr 100. 
bólu, a tylko życie wieczne"24. Ten zmysł wiary Ludu Bożego znajduje swoje najgłębsze teologiczne uzasadnienie w przywołanej już argumentacji odwołującej się do pierwotnej i fundamentalnej solidarności Chrystusa z każdym człowiekiem od momentu jego poczęcia, gdyż - jak czytamy w Liście do Kolosan - w Nim, przez Niego i dla Niego wszystko zostało stworzone (por. Kol 1,16-17). Do egzegetycznoteologicznej interpretacji tego hymnu powrócimy w dalszej części artkułu, gdyż jest on jednym z tych centralnych tekstów Nowego Testamentu, na podstawie którego uzasadniamy możliwość zbawienia zarówno dla dzieci zmarłych bez chrztu, jak i dla niechrześcijan, o których mowa jest w Konstytucji dogmatycznej o Kościele nr 16. Ta stwórcza solidarność Chrystusa z każdym człowiekiem (niektórzy nazywają ją „łaską pierworodną”) ma charakter nadprzyrodzony i w konsekwencji zbawczy.

\section{Zbawcza wiara w Chrystusa: czy jedynie wiara o charakterze explicite?}

Jak powiedziano na samym wstępie, wielu teologów ewangelikalnych uważa, że po śmierci i zmartwychwstaniu Jezusa do zbawienia jest konieczna wiara explicite $\mathrm{w}$ Niego ${ }^{25}$. Stąd, ich zdaniem, jedynym biblijnie i teologicznie właściwym paradygmatem $w$ chrześcijańskiej teologii religii jest paradygmat ekskluzywistyczny. Owszem, pośród teologów ewangelikalnych są także zwolennicy paradygmatu inkluzywistycznego. Niemniej jednak, zdaniem ich ekskluzywistycznych kolegów, pozycja inkluzywistyczna $\mathrm{w}$ świetle teleologii ewangelikalnej stanowi poważny błąd i jest nie do przyjęcia ${ }^{26}$. Jakie są ich argumenty? Odpowiedź znajdujemy w podstawowych tezach ewangelikalnej teologii ekskluzywistycznej. Po pierwsze, twierdzi się, że zbawienia nie można osiagnąć na podstawie tzw. „ogólnego objawienia" (general revelation) przez stworzenia i w stworzeniach, ale jedynie przez specjalne objawienia (special revelations), o których jest mowa w Starym i w Nowym Testamencie, a których punktem kulminacyjnym jest objawienie Boga w Jezusie Chrystusie. Po drugie, zdaniem teologów ewangelikalnych opcji ekskluzywistycznej, mówienie o „świętych poganach” na podstawie Biblii jest mitem, a nie rzeczywistością. Po trzecie, utrzymują oni, że po przyjściu Chrystusa jedyną zbawczą wiarą jest wiara o charakterze explicite w Jezusa Chrystusa. Innymi słowy, nie ma czegoś takiego jak ,anonimowi chrześcijanie” i wiara o charakterze implicite w Chrystusa. Po czwarte, utrzymuja, że promowany przez nich ekskluzywizm wypływa bezpośrednio z nauczania Pisma Świętego. To wszystko uzasadniane jest $\mathrm{w}$ krytycznym dialogu ze zwolennikami paradygmatu inkluzywistycznego wewnątrz teologii ewangelikalnej. Przypatrzmy się tym uzasadnieniom.

\footnotetext{
${ }^{24}$ Międzynarodowa Komisja Teologiczna, Nadzieja zbawienia dla dzieci zmartych bez chrztu, dz. cyt., nr 100 .

${ }^{25}$ Zob. np. R.H. Nash, Restrictivism, dz. cyt., s. 116. Ch.W. Morgan, R.A. Peterson, Answers to Notable Questions, dz. cyt., s. 249.

${ }^{26}$ Ch.W. Morgan, R.A. Peterson, Answers to Notable Questions, dz. cyt., s. 250-251.
} 


\section{Niewystarczalność „objawienia ogólnego"}

To, co teologowie katoliccy nazywaja , objawieniem przez stworzenia i w stworzeniach”, teologowie ewangelikalni nazywają „objawieniem ogólnym” (general revelation). Czy jest ono wystarczające do zbawienia? Zdaniem ewangelikalnych inkluzywistów: jest; natomiast zdaniem ewangelikalnych ekskluzywistów: nie jest. Zacytujmy zdania kilku najbardziej znanych pośród teologów ewangelikalnych opcji inkluzywistycznej, często przywoływanych w polemicznych artykułach przez ich współwyznawców ekskluzywistów. Clark Pinnock w swojej książce, The Flame of Love: A Theology of the Holy Spirit, pisze m.in.: „Nie ma ogólnego objawienia lub naturalnego poznania Boga, które jednocześnie nie byłoby łaskawym objawieniem i potencjalnie zbawczą wiedzą (gracious revelation and potentially saving knowledge)"27. Pinnock tłumaczy to powszechnym i zbawczym działaniem Ducha Świętego w świecie od momentu stworzenia. Tam, gdzie we wszechświecie działa Duch Święty, tam też jest Boże objawienie i Jego zbawcza łaska. A dzieje się to wszędzie. Dodać jeszcze należy, że zdaniem Pinnocka i innych ewangelikalnych inkluzywistów, jest to zawsze Duch Jezusa, tak samo jak jest On Duchem Boga ${ }^{28}$. Stąd, oparty na tym objawieniu i na tej Bożej łasce akt wiary człowieka ma charakter zbawczy, nawet jeśli nie jest to wiara o charakterze explicite w Jezusa Chrystusa.

Innym znanym ewangelikalnym inkluzywistą jest Terrance L. Tiessen, który swoje tezy przedstawił w książce Who Can Be Saved? Reassessing Salvation in Christ and World Religions ${ }^{29}$. Jego poglądy streścić możemy w kilku następujących punktach:

1. W Adamie wszyscy zgrzeszyli i zasługują na Boże potępienie. „Nie ma osób niewinnych, zarówno gdy chodzi o dzieci nienarodzone, niemowlęta, niepełnosprawnych, czy w pełni zdrowych osób dorosłych"30.

2. Jedynym Zbawicielem wszystkich jest Jezus Chrystus. Jest On przyczyną zbawienia każdego człowieka.

3. Zbawienia dostępują ci wszyscy, którzy wiarą odpowiedzieli na otrzymane objawienie: ogólne lub specjalne. Zdaniem Tissena: „Musimy oczywiście pamiętać, że pozytywna odpowiedź na każde Boże objawienie jest owocem Bożego łaskawego działania w sercu grzeszników, a nie odpowiedzią, która w naszej grzeszności przychodzi nam w sposób naturalny. Jeśli ta odpowiedź jest odpowiedzią wiary, to jest ona przez łaskę, co jest

${ }^{27}$ C.H. Pinnock, The Flame of Love: A Theology of the Holy Spirit, Downers Grove [USA, Illinois] 1996, s. 187.

${ }^{28}$ S.J. Wellum, Saving Faith. Implicit or Explicit?, w: Faith Comes by Hearing, dz. cyt., s. 149, przyp. 44.

${ }_{29}$ T.L. Tiessen, Who Can Be Saved? Reassessing Salvation in Christ and World Religions, Downers Grove [USA, Illinois] 2004.

${ }^{30}$ Tamże, s. 22. 
prawdziwe dla każdej wiary bez względu na pełnię objawienia, na które odpowiada"31, ponieważ Duch Święty działa tak samo w tych, co żyli przed Chrystusem, jak i w tych, co po Jego przyjściu nigdy o Nim nie słyszeli. Zbawcze działanie Ducha Świętego nie ogranicza się jedynie do ludu przymierza Starego i Nowego Testamentu.

4. W przypadku tych, którzy otrzymali jedynie objawienie ogólne, zbawcza wiara to odpowiedź człowieka na to objawienie wyrażona w akcie dziękczynienia Bogu jako Stwórcy i Żywicielowi, czyli jako temu, który człowieka stworzył i o niego się troszczy, a zatem jest to wiara w istnienie Boga oraz w opatrzność Bożą. W 7 tezie swojej książki Tiessen pisze: „Zbawienie zawsze było z łaski przez wiarę, ale wiara, jakiej Bóg oczekuje (i ją daje) jest odpowiednia do objawienia, jakie o sobie dał danej osobie. Od ludzi, którzy otrzymują ogólne objawienie, Bóg wymaga, aby Go czcili jako Stwórcę i Żywiciela (as the Creator and Provider), aby być $\mathrm{Mu}$ wdzięcznym, postępować zgodnie z sumieniem, i aby zawierzać się Jego miłosierdziu, kiedy mają świadomość złego postępowania. Jeśli w sercu kogokolwiek wielkodusznie Duch Boży wywołałby taką odpowiedź, ten byłby zbawiony" 32 . Swoją tezę o zbawczym charakterze ogólnego objawienia, nazywanego też „stwórczym objawieniem” (creational reveletion), czyli objawieniem w stworzeniach i przez stworzenia, Tiessen wywodzi z interpretacji Rz 1,18-23 oraz z ,przymierza kosmicznego" (cosmic covenant), jakie zostało objawione w przymierzu z Noem (Rdz 9,8-16). W interpretacji Rz 1,18-23 - tekstu, na podstawie którego (jak zobaczymy) ewangelikalni ekskluzywiści wyciągają wniosek, że ogólne objawienie jest jedynie podstawą do potępienia wszystkich ludzi, a nie do zbawienia kogokolwiek - Tiessen podkreśla, że jeśli z jednej strony objawienie ogólne, o którym mówi ten tekst, może być podstawą do potępienia tych, którzy je odrzucili, to $\mathrm{z}$ drugiej strony zawiera ono w sobie potencjał usprawiedliwienia dla tych, którzy je przyjmą i odpowiedzą pozytywnie ${ }^{33}$. Podobnie intepretuje on przymierze kosmiczne zawarte przez Boga z Noem. Zauważa, że „przymierze, jakie Bóg zawarł z Noem dotyczyło całej ludzkości i kosmosu (Rdz 9,10)"334. Odnotujmy, że w swojej argumentacji ten ewagelikalny inkluzywista odwołuje się do książki katolickiego teologa, Jacques'a Dupuis, Toward a Christian Theology of Religious Pluralism ${ }^{35}$.

${ }^{31}$ T.L. Tiessen, Who Can Be Saved? Reassessing Salvation in Christ and World Religions, dz. cyt., s. 142

32 Tamże, s. 138.

${ }^{33}$ Tamże, s. 140-143.

${ }^{34}$ Tamże, s. 144.

${ }^{35}$ J. Dupuis, Toward a Christian Theology of Religious Pluralism, New York 1997. 
5. Dla tych, którzy osobiście nie znają Chrystusa, owa zbawcza wiara w Niego ma charakter implicite. Jako przykład Tiessen przywołuje tu ludzi świętych (wierzących) z epoki Starego Testamentu - zarówno spośród Żydów, jak i pogan - stwierdzając, że ich wiara nie była wiarą w Chrystusa o charakterze explicite ${ }^{36}$. „Niewiele jest nam powiedziane o objawieniu, na które wierzący Starego Testamentu spoza ludu przymierza (np. Jetro) odpowiedzieli. Mogło to być ogólne objawienie lub resztki dużo wcześniejszego objawienia specjalnego. Myślę jednak, że najprawdopodobniej Bóg objawił się im osobiście, jak to uczynił ludowi przymierza. Na podstawie doświadczenia ludzi wierzących epoki Starego Testamentu możemy stwierdzić, że Bóg może zbawić ludzi dzisiaj, którzy nie słyszeli ewangelii. Mógłby ich łaskawie zbawić przez podobne środki objawienia i przez ten sam rodzaj wiary, zawierzenia Bogu i przyjęcia prawdziwości Jego obietnicy"37.

6. Ponadto Tiessen dopowiada, że podobnie jak w przypadku sprawiedliwych pogan z epoki Starego Testamentu oraz dzieci, które umierają wcześnie, tak samo u osób niezewangelizowanych z epoki po przyjściu Chrystusa owa wiara o charakterze implicite stanie się wiarą explicite w chwili ich spotkania z Chrystusem w momencie śmierci. Na pytanie, czy będą jacyś ludzie, którzy zostaną przyjęci w niebie przez Ojca, a którzy nie będą znali Syna, odpowiada, że jest to mało prawdopodobne, wręcz niemożliwe, gdyż jak czytamy w Mt 11,27: „Nikt nie przychodzi do Ojca jak tylko przez Syna”. $\mathrm{Ci}$, którzy nie znali Chrystusa za życia, mając jedynie wiare implicite w Niego, poznają go w chwili śmierci. „Uważam, że nawet ci, których Bóg łaskawie doprowadził do zbawczej relacji z Nim za ich życia, ale nie dał im wiedzy o wcieleniu Syna na drodze poznania Ojca, potrzebują poznać Syna. Moja propozycja - stwierdza Tiessen - o powszechnym spotkaniu w śmierci z Chrystusem pozwala na wyznanie, że wiara w Jezusa Chrystusa jest konieczna, jednak bez nadmiernego podkreślania konieczności poznania informacji o Chrystusie przed śmiercią"38.

Zdaniem teologów ewangelikalnych opcji ekskluzywistycznej, ani Pinnock, ani Tiessen, ani pozostali inkluzywiści nie mają racji, ponieważ objawienie ogólne nie ma charakteru zbawczego. Oceniając poglądy Tiessena, Stephen J. Wellum, profesor teologii w Southern Baptist Theological Seminary i zwolennik opcji ekskluzywistycznej, stwierdza, że ten ostatni swoimi poglądami odrzuca standardową ewangelikalną interpretację Rz 1,18-2239. Także Daniel Strange,

\footnotetext{
${ }^{36}$ T.L. Tiessen, Who Can Be Saved, dz. cyt., s. 165-203.

${ }^{37}$ Tamże, s. 165.

${ }^{38}$ Tamże, s. 217-218.

${ }^{39}$ S.J. Wellum, Saving Faith. Implicit or Explicit?, dz. cyt., s. 157.
} 
ewangelikalny teolog reformowany, wykładowca w Oak Hill Theological College w Londynie, uważa, że objawienie ogólne przez stworzenia i w stworzeniach nie ma charakteru zbawczego. Jak pisze, objawienie to jest wystarczające, ale nie dla zbawienia ${ }^{40}$. Jego uzasadnienie - jak w przypadku wszystkich teologów ewangelikalnych - jest oparte na właściwej dla tej opcji interpretacji istotnych tekstów biblijnych.

Pierwszym interpretowanym tekstem biblijnym jest Psalm 19,1-6, który mówi o ogólnym objawieniu. Na podstawie komentarzy egzegetów tej samej opcji ekskluzywistycznej Strange zauważa, że pierwszoplanowym celem psalmisty nie jest tu wskazanie na stworzenie jako kanał Bożego objawienia lub jako źródło wiedzy o Bogu poza objawieniem Mojżeszowym, ale na jedność Bożego objawienia przez stworzenia i w stworzeniach oraz specjalnego objawienia zawartego w Torze. Innymi słowy, ,jedynie w kontekście specjalnego objawienia i zbawienia ogólne objawienie Boga w stworzeniach może być właściwie zrozumiane"41. Oznacza to, że ci wszyscy, którzy nie otrzymali żadnego specjalnego objawienia, nie są w stanie właściwie zrozumieć ogólnego objawienia w stworzeniach i przez stworzenia. A zatem, samo ogólne objawienie nie jest wystarczające do zbawienia.

W podobnym duchu Strange interpretuje słynny tekst z Listu do Rzymian Rz 1,18-32. W uzasadnieniu powołuje się na egzegezę tego passusu przez Johana $\mathrm{H}$. Bavincka. Zdaniem tego holenderskiego teologa reformowanego XX wieku, kiedy Biblia mówi o ogólnym objawieniu, to nie ma na myśli jedynie prawdy o poznaniu istnienia Boga, lecz o trosce Boga o człowieka. „To jest - pisze boska troska o ludzi, kolektywnie i indywidualnie"42. Takie objawienie nie daje jednak człowiekowi zbawienia, ale nie $\mathrm{z}$ winy samego Boga, lecz z winy człowieka, który je nieustannie odrzuca. Komentując powyższy passus z Listu do Rzymian, holenderski teolog zauważa, że grzesznik nieustannie odrzuca to ogólne objawienie, zamieniając je na bałwochwalstwo, i dlatego też jest bez wymówki wobec Boga. Ilustracją tego czynu każdego człowieka może być obraz dziecka bawiącego się dużą piłką w wodzie. Próbuje ono z całych sił wepchnąć piłkę pod wodę, myśląc, że się uda. Jednak piłka zawsze wyskakuje na powierzchnię. Taka „gra” - zauważa Strange - toczy się między ogólnym objawieniem a jego odrzucaniem przez człowieka. Dokonuje się to zawsze i w każdej chwili. W każdej chwili człowiek Boga widzi i Go nie widzi, zna Go i już Go nie zna ${ }^{43}$. Oznacza to, że teoretycznie ogólne objawienie mogłoby wystarczyć do zbawienia, ale praktycznie nie wystarcza, u nikogo.

${ }^{40}$ D. Strange, General Revelation. Sufficient or Insufficient?, dz. cyt., s. 54-72.

${ }^{41}$ Tamże, s. 56.

${ }^{42}$ J.H. Bavinck, The Church Between Temple and Mosque, Eerdmans 1966, s. 124. Cyt. w: D. Strange, General Revelation. Sufficient or Insufficient?, dz. cyt., s. 60.

${ }^{43}$ D. Strange, General Revelation. Sufficient or Insufficient?, dz. cyt., s. 60-61. 
Podobnie Rz 1,18-32 intepretuje inny ewangelikalny ekskluzywista, Robert A. Peterson, profesor teologii w Covenant Theological Seminary. Jego zdaniem, Apostoł Narodów wyraźnie podkreśla, że w przypadku pogan ogólne objawienie jest jedynie na ich zgubę, gdyż z racji negatywnej na nie odpowiedzi „nie mogą wymówić się od winy" (Rz 1,20). Uważa, że - zdaniem Pawła - żaden człowiek nie odpowiedział pozytywnie na to objawienie ${ }^{44}$. Przeciwnie - jak widzieliśmy twierdzi Tiessen, którego zdaniem skoro Bóg dał człowiekowi ogólne objawienie, na podstawie którego (jeśli ten je odrzuci) może być potępiony, to należy przyjąć, że człowiek potencjalnie może również na to objawienie pozytywnie odpowiedzieć i osiagnąć zbawienie. $\mathrm{Z}$ taką tezą nie zgadza się Strange. Według niego ogólne objawienie w stworzeniach nie zawiera w sobie żadnej potencjalności zbawienia. Autor przyjmuje tu uzasadnienie Francisa Turretina, którego zdaniem przyjęcie czegoś jako dostateczne, by uznać grzechy człowieka za niewybaczalne, wcale nie oznacza, że jest to wystarczające do zbawienia człowieka. ,Zatem grzech pogan był niewybaczalny, ponieważ zastapili oni bogami bez liku miejsce jednego Boga, którego mogli poznać przez światło natury; ale nie możemy z tego wywnioskować, że poznanie jednego Boga jest absolutnie wystarczające do zbawienia" ${ }^{45}$. Wynika z tego, że objawienie ogólne jest jedynie po to, żeby usprawiedliwić Boga przed zarzutem oskarżenia Go o niesprawiedliwość w potępieniu tych wszystkich, którzy nie otrzymali jakiegoś specjalnego objawienia. Gdyby ktoś chciał postawić Bogu taki zarzut, Bóg mógłby mu odpowiedzieć: Dałem ci ogólne objawienie, które mówi o Mnie, ale go nie zrozumiałeś i od razu je odrzuciłeś. Fakt, nie mogłeś zrobić inaczej, gdyż, aby właściwie zrozumieć i z wiarą przyjać ogólne objawienie, potrzebne jest jeszcze specjalne objawienie. Ty go nie otrzymałeś. Ale czy możesz Mnie za to winić?

Tezę tę potwierdza także dokonana przez Strange'a interpretacja Rz 10,14-18. Jego zdaniem oraz zdaniem Petersona, w tym fragmencie, „Paweł nie mówi o możliwości zbawienia poprzez objawienie ogólne"46. Przedstawiony przez nich argument jest taki, że w tekście tym Paweł nie odnosi się do pogan, ale do Żydów, którzy nie byli adresatami ogólnego objawienia, lecz specjalnego objawienia, adresatami Ewangelii, która była im głoszona. Peterson podsumowuje:

List do Rzymian 10,9-18 bardziej niż jakikolwiek inny fragment Biblii podkreśla konieczność dla wszystkich grzeszników wiary w Jezusa, aby zostać zbawionym. [...] Dla grzeszników, by mogli doświadczyć zbawienia, Bóg musi wysłać kaznodzieję, który musi im przepowiadać, oni muszą o Jezusie usłyszeć, muszą w Niego uwierzyć, a nawet wzywać Go dla zbawienia. Współbrzmi to ze Starym Testamentem

${ }^{44}$ R.A. Peterson, Inclusivism versus Exclusivism on Key Biblical Textes, w: Faith Comes by Hearing, dz. cyt., s. 192.

${ }^{45}$ F. Turretin, Institues of Elenctic Theology, t. 3, Philipsburg [USA, New Jersey] 1992, 1:12.

Cyt. w: D. Strange, General Revelation. Sufficient or Insufficient?, dz. cyt., s. 59.

${ }^{46}$ D. Strange, General Revelation. Sufficient or Insufficient?, dz. cyt., s. 60-61. 
(Rz 10,14-15). Reasumując: „wiara rodzi się z tego, co się słyszy, tym zaś, co się słyszy, jest słowo Chrystusa" (Rz 10,17). Nie ma zatem nic dziwnego, że Rz 10,9-17 wraz z J 14,6 i Dz 4,12 są ulubionymi tekstami ekskluzywistów ${ }^{47}$.

\section{Zbawcza wiara: o charakterze implicite czy explicite?}

To, że zbawienie każdego człowieka dokonuje się przez wiarę w Jezusa Chrystusa, jest doktryną przyjmowaną przez wszystkich teologów ewangelikalnych. Różnica między inkluzywistami i eksluzywistami dotyczy charakteru tej wiary: Czy dla wszystkich musi to być wiara explicite czy wystarczy wiara implicite?

Jak mogliśmy zauważyć, zdaniem Tiessena, niezewangelizowani mogą osiagnąć zbawienie na bazie wiary implicite w Chrystusa dzięki powszechnemu działaniu Ducha Świętego. Ta wiara niewyraźna za życia w momencie ich śmierci przekształci się w wiarę o charakterze explicite. Ponadto Tiessen zauważa, że nie jest konieczne zakładanie, iż ich zbawienie dokonało się jedynie drogą ogólnego objawienia $^{48}$. W przypadku Izraelitów było to z pewnością także specjalne objawienie Mojżeszowe. Podobnie mogło być w przypadku niektórych pogan jak Mechizedek i Jetro. Niemniej jednak, ich wiara w Chrystusa nie miała charakteru explicite. „Biblijne przykłady wyżej zacytowane [wierzących epoki Starego Testamentu] pokazuja, że ktoś może być zbawiony przez Chrystusa bez wiedzy o Nim, przynajmniej bez wiedzy przekazanej przez posłańca, i to dostarcza nam podstaw do nadziei, że Bóg działa ze swoją łaską poza Kościołem również dzisiaj" "49. Podobnie jak wielu katolickich teologów, także Tiessen uważa, że Boża ekonomia zbawienia nie zakłada, iż następujące po sobie przymierza znoszą jedno drugie. Pisze:

W terminach historii zbawczego działania Boga nowe przymierze jasno zostało zainaugurowane, a Duch został teraz dany wszystkim, którzy wierzą w Jezusa. Niemniej jednak, twierdzę, że ponieważ z definicji niezewangelizowani nie znają Jezusa, zatem żyją oni w innej „duchowej ekonomii” i oczekują pełnego objawienia Boga w Chrystusie, podobnie jak wierzący przed wcieleniem Słowa Bożego ${ }^{50}$.

Podobne argumenty spotkać można u innych ewangelikalnych teologów opcji inkluzywistycznej. Zdaniem Stephena Welluma, ich teza na rzecz wiary implicite w Chrystusa jest nie do przyjęcia przez ortodoksyjną teologię ewangelikalną ${ }^{51}$. Na podstawie licznych cytatów biblijnych stwierdza on najpierw, że powszechne działanie Ducha, o którym jest mowa w Starym i Nowym Testamen-

\footnotetext{
${ }^{47}$ R.A. Peterson, Inclusivism versus Exclusivism on Key Biblical Textes, dz. cyt., s. 197.

${ }^{48}$ T.L. Tiessen, Who Can Be Saved?, dz. cyt., s. 151-157.

${ }^{49}$ Tamże, s. 180.

${ }^{50}$ Tamże, s. 227.

${ }^{51}$ S.J. Wellum, Saving Faith. Implicit or Explicit?, dz. cyt., s. 161-183.
} 
cie, „nie zawsze powinno być utożsamiane z działaniem Ducha w zbawczej łasce" 52 . Następnie zauważa, że wiara osób „wierzących”/,świętych” z epoki Starego Testamentu, takich jak Abraham czy Noe, opierała się nie na ogólnym objawieniu, lecz na specjalnym objawieniu. Zauważa też, że wiara Abrahama miała charakter wiary explicite w Jezusa Chrystusa. Pisze:

Wiara Abrahama musi być postrzegana jako wiara explicite, ponieważ wierzył on w Boże obietnice - obietnice skoncentrowane na Bożej zapowiedzi Odkupiciela (God's provision of a Redeemer) (Rdz 3,15), skoncentrowane na Bogu, który daje (God who provides) (Rdz 22,14). Czy Jezus Chrystus był przedmiotem jego wiary? Najlepsza odpowiedź na to pytanie, brzmi: tak i nie. Nie - w tym sensie, że Abraham nie wiedział, iż to Jezus był potomstwem kobiety [Ewy]; ale tak - bo jego wiara była wiarą w Bożą obietnicę skoncentrowaną na obiecanym potomstwie, które ostatecznie, w miarę rozwoju Bożego planu, bezpośrednio prowadzi nas do Chrystusa. Możemy zatem na pewno powiedzieć, że wiara Abrahama była wiarą specjalną, zdefiniowaną przez przymierze (zob. Rz 4,13-25) ${ }^{53}$.

Ponieważ przypadek Abrahama jest centralny w rozważaniach ekskluzywistów, warto przytoczyć jeszcze kilka cytatów innych teologów tej opcji. W artykule poświęconym „świętym poganom”, Walter C. Kaiser Jr., wykładowca Starego Testamentu w Gordon-Conwell Theological Seminary, najwięcej miejsca poświęca Abrahamowi ${ }^{54}$. Centralne pytanie, jakie stawia, brzmi: Co było przedmiotem wiary Abrahama? Odpowiada, że obietnica dana Abrahamowi w Rdz 12,1-3 dotyczyła trzech rzeczy: potomka, kraju i Dobrej Nowiny/Ewangelii: „Przez ciebie będą otrzymywały błogosławieństwo wszystkie ludy ziemi”. Rozdziały 13 i 14 Księgi Rodzaju skupione są na obietnicy ziemi. W rozdziale 15 powraca obietnica potomka. Bóg obiecuje Abrahamowi, że jego potomstwo będzie tak liczne, jak gwiazdy na niebie ( $\operatorname{Rdz} 15,4-5)$, po czym padają słowa: „Abraham uwierzył i Pan poczytał mu to za zasługę” (Rdz 15,6). Odpowiadając na postawione wyżej pytanie, Kaiser przytacza najpierw wypowiedzi dwóch teologów. Żyjący w XIX wieku, Franz Delitzsch napisał: „Obietnica [...] prawdziwie posiada Chrystusa za swój przedmiot; [...] wiara, z jaką Abraham ją przyjmuje, jest wiarą w obiecane potomstwo" 55 . Podobna jest odpowiedź luterańskiego teologa XX wieku, Herberta C. Leupolda, który pisał: „Rodzi się teraz pytanie: Czy wiara Abrahama jest różna od usprawiedliwiającej wiary wierzących Nowego Testamentu? Bez wahania i stanowczo odpowiadamy: Nie. Centralną kwestią

${ }^{52}$ Tamże, s. 166-167.

${ }^{53}$ Tamże, s. 174.

${ }^{54}$ W.C. Kaiser Jr, Holy Pagans. Reality or Myth?, w: Faith Comes by Hearing, dz. cyt., s. $124-130$.

${ }^{55}$ F. Delitzsch, A New Commentary on Genesis, trans. S. Taylor, 1888, reprint, Minneapolis 1978, 2:7. Cyt. w: W.C. Kaiser Jr, Holy Pagans. Reality or Myth?, dz. cyt., s. 127. 


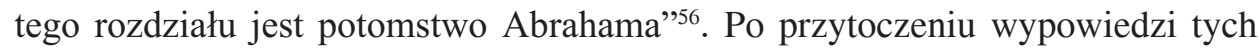
dwóch teologów z XIX i XX wieku, sam Kaiser oświadcza:

Leupold, Delitzsch i ja nie twierdzimy, że Abraham lub jakakolwiek inna osoba ze Starego Testamentu posiadała pełne rozumienie przyszłego imienia i zbawczego dzieła Jezusa Zbawiciela. Raczej argumentujemy, że podstawowym przedmiotem wiary dla wierzących Starego Testamentu był nikt inny jak Człowiek Obietnicy, Mesjasz, który miał przyjść, i który później został objawiony jako nasz Pan Jezus ${ }^{57}$.

Chodzi o potomka, który już na samym początku historii zbawienia został obiecany Ewie (Rdz 3,15).

Jak wynika chociażby z tej wypowiedzi, zdaniem teologów ewangelikalnych opcji ekskluzywistycznej także wiara pozostałych „wierzących” Izraelitów epoki Starego Testamentu miała charakter wiary explicite podobnej do wiary Abrahama. Była to bowiem wiara zakorzeniona w Bogu Biblii i w Jego obietnicach wypływających z przymierza, jakie zawarł z Izraelem, a które zapowiadało i wskazywało na Jezusa ${ }^{58}$. Pisze o tym Donald A. Carson: ,Z perspektywy biblijnej narracji istnieje prawdziwa kontynuacja między świętymi Starego Testamentu a świętymi Nowego Testamentu (por. Rz 1,-2; 11,1-36; Flp 3, 3.7.9). W czasie starego przymierza instytucje, systemy ofiarnicze oraz cały porządek kapłański, były ze strony ludu przestrzegane jako część porządku wiary, ale te instytucje i systemy również wskazywały [...] na Jezusa Chrystusa - na Jego ofiarę, Jego kapłaństwo, niebieskie tabernakulum, i tak dalej" ${ }^{59}$. Zatem, wiara „świętych” Izraelitów epoki Starego Testamentu była wiarą explicite w Chrystusa jako potomka Ewy i potomka Abrahama, który miał przyjść.

W tym punkcie należy kilka słów powiedzieć na temat ich interpretacji słynnego tekstu z Listu do Hebrajczyków: „Bez wiary zaś nie można podobać się Bogu. Przystępujący bowiem do Boga musi wierzyć, że [Bóg] jest i że wynagradza tych, którzy Go szukają" (Hbr 11,6). W Kościele katolickim istnieje silna tradycja interpretacji tego tekstu dla poparcia paradygmatu inkluzywistycznego. Także niektórzy teologowie ewangelikalni, jak wspomniani chociażby Pinnock i Tiessen, przywołują ten fragment dla biblijnego uzasadnienia opcji inkluzywistycznej. Wskazują, że minimalna wiara wymagana do zbawienia, to wiara w Boga jako Stwórcę i Żywiciela (as the Creator and Provider), czyli wiara w istnienie Boga i Jego Opatrzność. Z tym, oczywiście, polemizują ich współwyznawcy opcji ekskluzywistycznej. Ich pozycję dokładnie przedstawia Robert

${ }^{56}$ H.C. Leupold, Exposition of Genesis, Grand Rapids 1953, 1: 478. Cyt w: W.C. Kaiser Jr, Holy Pagans. Reality or Myth?, dz. cyt., s. 127.

${ }^{57}$ W.C. Kaiser Jr, Holy Pagans. Reality or Myth?, dz. cyt., s. 127.

${ }^{58}$ S.J. Wellum, Saving Faith. Implicit or Explicit?, dz. cyt., s. 174-175.

${ }^{59}$ D.A. Carson, The Gagging of God: Christianity Confronts Pluralism, Grand Rapids 1996, s. 298. Cyt. w: S.J. Wellum, Saving Faith. Implicit or Explicit?, dz. cyt., s. 175. 
Peterson. Zauważa, że - po pierwsze - jeśli chcieć wydobyć z tego fragmentu „zasadę wiary”, to będzie ona opierała się na przymierzu Boga z Izraelem w Starym Testamencie. Zatem, przedmiotem tej wiary nie jest ogólne objawienie, ale jest nim specjalne objawienie ${ }^{60}$. Po drugie, należy stwierdzić, że treść wiary, o której mówi Hbr 11,6, nie wyczerpuje całego nauczania ani Biblii, ani nawet Listu do Hebrajczyków na temat treści wiary, gdzie ta zdefiniowana jest w terminach chrystologicznych (por. Hbr 10,19.21, 23; 12,1-2) ${ }^{61}$. Dlatego, zdaniem Petersona, niewłaściwe jest redukowanie zbawczej wiary do wiary w to, że Bóg jest i że wynagradza tych, którzy Go szukają. Po trzecie, obecna w Hbr 11,6 „zasada wiary" musi być interpretowana w kontekście postępu biblijnego objawienia.

Oznacza to, że metodologicznym błędem inkluzywizmu jest powoływanie się na teksty opisujące zbawienie świętych Starego Testamentu, aby mówić o Bożych wymaganiach dla niezewangelizowanych dzisiaj. Niemądre - pisze - jest mieć nadzieję zbawienia niezewangelizowanych na bazie inkuzywistycznej „zasady wiary”. To, czego niezewangelizowani naprawdę potrzebują, to usłyszeć i uwierzyć w ewangelię Chrystusa $^{62}$.

Powiedzieliśmy wyżej, że zdaniem ewangelikalnych ekskluzywistów, ,wierzący"/,święci” Izraelici epoki Starego Testamentu mieli wiarę explicite w Chrystusa. A co odnośnie do pogan, np. Melchizedeka? Jak zauważa w swoim tekście Kaiser, przypadek Melchizedeka jest wielkim wyzwaniem, gdyż przedstawiony jest on jako „król Szalemu” i jako „kapłan Boga Najwyższego” (Rdz 14,18). Ten kananejski król i kapłan błogosławił Abrahama w ,imię Boga Najwyższego, Stwórcę nieba i ziemi" (Rdz 14,19). Ponadto Abraham dał mu dziesiątą część ze wszystkiego, co zdobył (Rdz 14,20). Próbując właściwie zinterpretować ten tekst i zrozumieć rodzaj wiary Melchizedeka, Kaiser stawia dwa arcyciekawe pytania: „Gdyby zatem Melchizedek nie był prawdziwym wierzącym, dlaczego Abraham dałby mu dziesięcinę, która zazwyczaj odłożona była dla jednego prawdziwego Boga, który właśnie dał mu bezprecedensowe zwycięstwo, a którą Abraham przekazał komuś kto inaczej postrzegany byłby jako pogański kapłan kananejskiego bóstwa?"63. W tym pytaniu zawarta już jest odpowiedź Kaisera, który uważa, że Melchizedek miał taką samą wiarę jak Abraham i inni święci Izraelici Starego Testamentu, że wierzył w Człowieka Obietnicy, czyli w Jezusa Chrystusa, który był obiecany i miał przyjść. A oto drugie jego pytanie: „Gdzie, kiedy i jak ten kapłan i król pośród pogańskiej kultury stał się wierzącym w Człowieka Obietnicy (Man of Promise), którego - wydaje się - rozpoznaje on z zasady w swoim

\footnotetext{
${ }^{60}$ R.A. Peterson, Inclusivism versus Exclusivism on Key Biblical Textes, dz. cyt., s. 198.

${ }^{61}$ Tamże, s. 198-199.

${ }^{62}$ Tamże, s. 199.

${ }^{63}$ W.C. Kaiser Jr, Holy Pagans. Reality or Myth?, dz. cyt., s. 130.
} 
uwielbieniu dla Boga nieba i ziemi?" ${ }^{64}$. Kaiser zauważa, że tekst nie odpowiada na to pytanie, gdyż nie to stanowi istotę jego przesłania.

Także jeśli chodzi o Jetro, kapłana Madianitów i teścia Mojżesza, Kaiser odnotowuje, że nie wiemy, kiedy, gdzie i jak Jetro po raz pierwszy uwierzył. Niemniej jednak, należy przyjąć, że jego wiara była wiarą zbawczą w prawdziwego Boga, gdyż Pan przyjął jego ofiarę (Wj 18). Amerykański teolog konkluduje: „Niektórzy mogą nazywać Jetrę świętym poganinem, ponieważ nie był Żydem. Ale w każdym aspekcie jawi się on jako wierzący w pełnej wspólnocie z ludem Boga"65.

Jeśli chodzi o Nowy Testament, emblematyczną postacią jest Korneliusz, którego historia opisana jest w rozdziale 10. Dziejów Apostolskich. Ewangelikalni inkluzywiści uważają go za ,świętego poganina”, który miał zbawczą wiarę przed przybiciem do niego św. Piotra z Ewangelią o Jezusie Chrystusie. Ewangelikalni ekskluzywiści to kontestują. Wellum oświadcza: „Nie uważam, że tekst mówi, iż został on [Korneliusz] zbawiony przed przyjęciem wiary w Jezusa Chrystusa" ${ }^{66}$. Kaiser natomiast stwierdza: „Zasada zilustrowana przez Korneliusza wydaje się mówić, że tam gdzie ludzie żyją światłem, jakie posiadają, Bóg wyśle posłańca, aby im powiedzieć o ewangelii naszego Pana Jezusa Chrystusa" ${ }^{" 67}$.

Podsumowując, należy stwierdzić, że ewangelikalni ekskluzywiści nie przeczą temu, że „wierzący”, czyli „świeci poganie”, epoki Starego Testamentu, jak Abraham, Melchizedek i inni, mogli mieć zbawczą wiarę i osiąnąć zbawienie. Jednoznacznie to akceptują. Niemniej jednak, twierdzą, że wiara ta była wiara explicite w Jezusa Chrystusa. Dodają jednak, że charakteru explicite tej wiary nie należy rozumieć $\mathrm{w}$ tym sensie, że bezpośrednim przedmiotem ich wiary była osoba i dzieło Jezusa Chrystusa. Uczciwie przyznaja, że nawet Abraham takiej wiary nie miał. Niemniej jednak, twierdzą, że oni wszyscy mieli za przedmiot wiary (the object of faith) potomka Ewy i potomka Abrahama, który miał przyjść, który rozumiany był jako Człowiek Obietnicy, jako Mesjasz itp., i który był zapowiedzią Jezusa Chrystusa. W tym sensie mieli oni wiarę w Chrystusa bez względu na to, jak małą, czy jak wielką mieli wiedzę o Jego życiu i dziele ${ }^{68}$.

\section{Ocena z perspektywy teologii katolickiej}

To krytyczne podsumowanie zacznijmy od pytania: Czy zbawcza wiara świętych pogan epoki Starego Testamentu rzeczywiście miała charakter wiary explicite w Chrystusa? Z historii wiemy, że tak uważał św. Augustyn. Jednak kiedy

\footnotetext{
${ }^{64}$ W.C. Kaiser Jr, Holy Pagans. Reality or Myth?, dz. cyt., s. 130.

${ }^{65}$ Tamże.

${ }^{66}$ S.J. Wellum, Saving Faith. Implicit or Explicit?, dz. cyt., s. 178.

${ }^{67}$ W.C. Kaiser Jr, Holy Pagans. Reality or Myth?, dz. cyt., s. 139.

${ }^{68}$ Tamże, s. 140.
} 
biskup Hippony twierdził, że święci epoki Starego Testamentu mieli wiarę explicite w Chrystusa, to rozumiał przez to wiarę we wcielenie, mękę i zmartwychwstanie Chrystusa. Pisze o tym w Contra Duas Epistolas Pelagianorum. W księdze trzeciej, rozdział IV, 11, Hippończyk podejmuje temat różnicy między sprawiedliwymi Starego i Nowego Testamentu. Zauważa, że ci wszyscy, którzy znajdują się pod wpływem łaski, czynią to, co jest zgodne $\mathrm{z}$ wiara, zwłaszcza wierzą w Pośrednika. Dalej stwierdza, że tego typu ludźmi byli sprawiedliwi dawnych czasów, ,ponieważ - tłumaczy - tą samą wiarą, którą my żyjemy, także oni żyli, wierząc we wcielenie, mękę i zmartwychwstanie Chrystusa" ${ }^{\prime 9}$. Nie była to zatem (jedynie) wiara implicite, ale wiara wyraźna, wiara explicite. Jedyna różnica jest taka, że dla nich te prawdy wiary były przyszłością, a dla nas są przeszłością. „Czasy się zmieniają, ale nie wiara” (Tempora varianta sunt, non fides). Jak komentuje Louis Capéran, jest to jedno z ulubionych zdań Hippończyka, na które natrafić można w wielu jego pismach ${ }^{70}$. Święty Tomasz z Akwinu wprowadzał już rozróżnienie na wiarę explicite i wiarę implicite u świętych epoki Starego Testamentu. Niektórzy z nich, zwani maiores (,znaczni”, „wielcy"), mieli wiarę explicite w Chrystusa i Trójcę Świętą; inni, zwani minores (,prostaczkowie”, „mali”), mieli wiarę implicite. Pisał:

Po upadku zaś wierzono wyraźnie w tajemnicę wcielenia Chrystusa, i to nie tylko w samo wcielenie, ale również w mękę i zmartwychwstanie, którymi miał być ród ludzki uwolniony od grzechu i śmierci; inaczej nie przedstawiano by męki Chrystusa za pomocą niektórych ofiar i to tak przed, jak i po ogłoszeniu prawa (Mojżeszowego); a sens tych ofiar jasno rozumieli ludzie znaczniejsi; prostaczkowie zaś, pod zasłoną tych ofiar, dopatrując się, z rozporządzenia Bożego, przyszłego Chrystusa, posiadali poniekąd zamglone poznanie; $i$, jak to wyżej powiedziano, to, co dotyczy tajemnic Chrystusa, tym dokładniej poznawali, im bliższymi byli Chrystusa ${ }^{71}$.

Wydaje się, że kiedy teologowie ewangelikalni piszą o zbawczej wierze wierzących Żydów i pogan epoki Starego Testamentu, to myślą o wierze w Chrystusa o charakterze implicite, podobnie jak wiara ,prostaczków” w przytoczonym wyżej cytacie Akwinaty. Zreszta, odpowiedź „Tak i Nie”, jakiej Wellum udziela na pytanie: Czy Jezus był przedmiotem wiary Abrahama? - to potwierdza. Ewangelikalni teologowie opcji ekskluzywistycznej zatem twierdzą, że ci wszyscy święci Żydzi i poganie epoki Starego Testamentu mieli zbawczą wiarę w Chrystusa, ale co do treści nie była to $\mathrm{w}$ sensie ścisłym wiara explicite, lecz wiara implicite. Pytanie brzmi: Jaka była minimalna treść tej wiary? Na podstawie przeprowadzonych wyżej analiz możemy powiedzieć, że - w ich opinii - minimalną

\footnotetext{
${ }^{69}$ Augustyn, Contra Duas Epistolas Pelagianorum, księga III, rozdz. IV, 11 (PL, kol. 595).

${ }^{70}$ L. Capéran, Le probleme du salut des infi deles, t. 1: Essai historique, Paris 1912, s. 119-120.

${ }^{71}$ Tomasz z Akwinu, Suma teologiczna, tłum. Pius Bełch OP, London 1966, II-II, q. 2, a.7.
} 
treścią zbawczej wiary w Chrystusa była wiara w Człowieka Obietnicy (Man of Promise). Taką wiarę miał Abraham. Taką wiarę miał również Melchizedek.

Dla mnie ich interpretacja biblijnych tekstów dotyczących zwłaszcza wiary Melchizedeka (by ograniczyć się do jednego przykładu) nie jest do końca przekonująca, podobnie jak nie jest przekonująca ich egzegeza Hbr 11,6. Owszem, zgadzam się z nimi, że zbawcza wiara jest wiarą w Chrystusa, bo tylko On jest Panem i Zbawicielem, i nie ma innego imienia (Dz 4,12). Niemniej jednak, mam duże waţpliwości co do proponowanej przez nich minimalnej treści tej wiary implicite w Chrystusa. Na podstawie tradycji teologii katolickiej uważam, że minimalna treść zbawczej wiary w Chrystusa o charakterze implicite - nie tylko dla tych, którzy żyli przed wcieleniem, ale także dla żyjących po przyjściu Chrystusa na ziemię - zawarta jest w wierze w Człowieka, w jego niezbywalną godność i w uczciwe życie zgodnie z nakazem sumienia ${ }^{72}$; co następnie i pełniej urzeczywistnia się w wierze w istnienie Boga jako Stwórcy i w Jego Opatrzność; co dalej urzeczywistnia się w wierze w Człowieka Obietnicy i w Mesjasza; co ostatecznie i w pełni urzeczywistnia się w wierze w Jezusa Chrystusa, Pana i Zbawiciela. Gdyby było inaczej, należałoby uznać za błędne nauczanie Soboru Watykańskiego II w Konstytucji dogmatycznej o Kościele, Lumen gentium, nr 16. Uzasadnieniem biblijnym będzie tu inna niż ewangelikalnych teologów ekskluzywistycznych interpretacja takich tekstów jak: Rz 1,18-23; Rz 2,14-16 i Hbr 11,6, oraz całkowicie pomijanego przez tych teologów tekstu Kol 1,15-20. Zacznijmy od interpretacji chrystologicznego hymnu z Listu do Kolosan.

15 On jest obrazem Boga niewidzialnego - Pierworodnym wobec każdego stworzenia, 16 bo w Nim zostało wszystko stworzone: i to, co w niebiosach, i to, co na ziemi, byty widzialne i niewidzialne, czy Trony, czy Panowania, czy Zwierzchności, czy Władze. Wszystko przez Niego i dla Niego zostało stworzone. 17 On jest przed wszystkim i wszystko w Nim ma istnienie. 18 I On jest Głową Ciała - Kościoła. On jest Początkiem, Pierworodnym spośród umarłych, aby sam zyskał pierwszeństwo we wszystkim. 19 Zechciał bowiem [Bóg], aby w Nim zamieszkała cała Pełnia, 20 i aby przez Niego znów pojednać wszystko z sobą: przez Niego - i to, co na ziemi, i to, co w niebiosach, wprowadziwszy pokój przez krew Jego krzyża. (Kol 1,15-20)

Egzegeci zgodnie podkreślają, że hymn ten zawiera dwa zasadnicze stwierdzenia, przedstawione $\mathrm{w}$ dwóch dających się łatwo wyróżnić strofach ${ }^{73}$. W strofie pierwszej (15-18a) wywyższony Chrystus ukazany jest jako istniejący przed wszelkim stworzeniem oraz jako pośrednik wszelkiego stworzenia, tak że nie było stwo-

${ }^{72}$ Myślę, że przykładem takiej osoby może być Janusz Korczak. Choć miał pochodzenie żydowskie, w Boga nie wierzył. Wierzył jednak w niezbywalną godność osoby ludzkiej i oddał swoje życie, służąc do końca dzieciom.

${ }^{73}$ Zob. J.N. Aletti, Saint Paul - Epitre aux Colossiens. Introduction, traduction, commentaire, Paris 1993, s. 91-92; M.E. Boismard, A l'aube du christianisme. Avant la naissance des dogmes, Paris 1998, s. 88; F.J. Matera, New Testament Christology, Luisville [USA, Kentucky] 1999, s. 139. 
rzenia bez Niego. W strofie drugiej (18b-20) stwierdza się, że przez Niego, wywyższonego Pana, wszystkie rzeczy - na ziemi i w niebie - zostały odkupione i pojednane z Bogiem. Zatem dwoma wielkimi tematami hymnu są: stworzenie wszystkiego w Chrystusie oraz odkupienie i pojednanie wszystkiego przez Niego, co strukturalnie wyrażone jest w sformułowaniach: „w Nim”, „przez Niego”, „dla Niego”. Logika myślenia wychodzi zatem od ukazania roli Chrystusa w stworzeniu (strofa pierwsza) i zmierza ku ukazaniu Jego roli w odkupieniu (strofa druga), od ukazania Jego relacji z pierwszym stworzeniem (protologia), ku wskazaniu Jego relacji z nowym odkupionym stworzeniem (eschatologia).

W swoim komentarzu, francuski, katolicki egzegeta i znawca teologii św. Pawła, Jean-Noël Aletti, zauważa, że Bóg - autor dzieł stworzenia, odkupienia i pokoju - jest jakby nieobecny. Nie ma o Nim w hymnie mowy. Interesujący jest wniosek, jaki z tego wyciaga Aletti. Stwierdza mianowicie, że ,akcent jest położony nie na Boże działania [...], ale na jedynego pośrednika, dzięki któremu te działania były możliwe, oraz przez którego i dla którego były one zrealizowane"74. Innymi słowy, hymn jest skoncentrowany na relacji, jaka istnieje między Jezusem Chrystusem a wszystkim innym. Komentując werset 16., Aletti stwierdza, iż jest w nim mowa o tym, że wszystko zostało stworzone nie tylko „w Nim” i „przez Niego”, ale także „dla Niego”, co znacznie przekracza starotestamentową funkcję i rolę Mądrości. Nigdzie bowiem w Starym Testamencie nie jest powiedziane, że wszystko było stworzone dla Mądrości ${ }^{75}$. Ponadto, w odróżnieniu od tożsamości starotestamentowej Mądrości, która jest stworzeniem Boga, w hymnie nie ma mowy o stworzeniu Jezusa Chrystusa, lecz o stworzeniu wszystkiego przez Niego i dla Niego.

Komentując werset $15 \mathrm{~b}$ - ,pierworodny wobec każdego stworzenia” (prototokos pases ktiseos) oraz werset 17 - „On jest przed wszystkimi rzeczami” (pro panton), Aletti uważa, że pośrednictwo Chrystusa w stworzeniu wymaga afirmacji Jego rzeczywistej preegzystencji wobec wszelkiego stworzenia. Dlatego jednoznacznie stwierdza, że w Kol 1,15-20 pośrednictwo Chrystusa w dziele stworzenia zakłada preegzystencję, po czym precyzuje, że w preegzystencji tej nie chodzi o rozróżnienie między odwiecznym Logosem i zrodzonym z Maryi Chrystusem. Pisze: „Tytuł «Syn» z wiersza 13. ma właśnie na celu przekroczenie wszelkiego rozróżnienia, o którym można by było myśleć, że istnieje między preegzystującym Logosem i (ludzkim, ziemskim) Chrystusem"”76.

Francuski teolog, Joseph Moingt, rozwija tę interpretację. Zauważa, że wszystkie oświadczenia proklamacji chrystologicznej tego hymnu pochodzą z refleksji nad zwycięstwem Chrystusa na Krzyżu. Ono jest punktem odniesienia

\footnotetext{
${ }^{74}$ J.N. Aletti, Saint Paul - Epitre aux Colossiens, dz. cyt., s. 93.

${ }^{75}$ Tamże, s. 101-102 i 114-116.

76 Tamże, s. 117.
} 
i wyjścia. Innymi słowy, jest nim eschatologiczne zwycięstwo Chrystusa na Krzyżu, jak czytamy w wierszu 20.: „Zechciał bowiem [Bóg] [...] aby przez Chrystusa znów pojednać wszystko ze sobą: przez Niego - i to, co na ziemi, i to, co w niebiosach, wprowadziwszy pokój przez krew Jego krzyża”. Moingt tłumaczy, że kiedy wierzący kontempluje końcowe zwycięstwo Chrystusa jako realizację Bożego planu zbawienia, jego refleksja wiary kieruje się ku początkowi tego planu, i w ten sposób następuje przejście od eschatologii ku protologii, od teologii zbawienia do teologii stworzenia. „Jeśli do Chrystusa należy doprowadzenie Bożego planu do końca, to dlatego [...] że Bóg odwiecznie chciał stworzenia ze względu na królestwo swego Syna, ze względu na życie wieczne, jakie Jego miłość chciała udzielić swoim stworzeniom przez Chrystusa i w Nim"”77. W ten sposób podkreślona zostaje powszechność zbawcza wydarzenia paschalnego. Od samego początku żadne stworzenie nie wymyka się spod władzy Chrystusa ani nie jest wykluczone ze zbawienia, ponieważ On jest zasadą i racją wszelkiego stworzenia: „bo w Nim zostało wszystko stworzone” (w. 16). Innymi słowy, Chrystus jest pośrednikiem wszelkiego zbawienia, ponieważ z racji odwiecznego planu Boga jest On także pośrednikiem wszelkiego stworzenia. Jak zauważa Moingt, racją, dla której wiara chrześcijańska, zawarta w tym hymnie, stwierdza, iż Chrystus jest ,pierworodnym wobec każdego stworzenia” (w. 15), jest to, że jest On ,pierworodnym spośród umarłych” (w. 18). Moingt pisze:

W ten sposób odkryte zostaje odwieczne istnienie Chrystusa jako Syna Bożego, ale bez możliwości odcięcia Go od Jego historyczności, jaką jest Jego solidarność ze stworzeniami, których ,pełnię” On w sobie gromadzi. Innymi słowy, hymn nie objawia ukrytego istnienia w Bogu hipostazy, która nie miałaby relacji z czasem, ani ze światem, ale odsłania podwójną przynależność Chrystusa do wiecznego statusu bytu Bożego oraz do porządku stworzenia ${ }^{78}$.

Egzegeza Kol 1,15-20 jednoznacznie pokazuje, że Jezus Chrystus nie jest jedynie u początku dzieła zbawienia. On jest również u początku dzieła stworzenia. Oznacza to, że zarówno łaska stwórcza, jak i każda inna udzielona wszelkiemu stworzeniu, już jest łaską Jezusa Chrystusa. Wychodząc od Kol 1,15 oraz na podstawie reinterpretacji Rdz 2,7 zawartej w 1 Kor 15,45, Jacek Bolewski opisuje tajemnicę Syna Bożego, by stwierdzić, że

już od początku w Adamie ukryty był Chrystus i właśnie On przekazywał potomkom Adama życie Boże, łaskę - jeszcze przed objawieniem w Jezusie. Rozpoznanie tej łaski dokonało się w Tradycji w odniesieniu do Maryi, w związku z Jej niepokalanym poczęciem. Okazało się, że łaska działała w tym przypadku od początku życia, jeszcze przed przyjściem na świat Jezusa. Wprawdzie w Maryi łaska była szczegól-

${ }_{77} \mathrm{~J}$. Moingt, Dieu qui vient à l'homme, t. 2: De l'apparition à la naissance de Dieu, 1: Apparition, Paris 2005, s. 90.

${ }^{78}$ Tamże, s. 98. 
nego rodzaju, jako że znosiła grzech pierworodny. Skoro jednak Pawłowa interpretacja pozwala przyjąć, że już u pierwszego człowieka przekazywanie łaski wiązało się z Chrystusem, to chociaż Adam utracił dla siebie i swych potomków otrzymane dary, jednak ukryta w nim „,pierworodna łaska” związana z Chrystusem była właśnie przez Niego przekazywana wszystkim potomkom Adama, którzy na skutek jego grzechu byli obciążeni pierworodnym grzechem ${ }^{79}$.

Dobrym komentarzem do Kol 1,15-20 mogą być także słowa Międzynarodowej Komisji Teologicznej w dokumencie Nadzieja zbawienia dla dzieci zmartych bez chrztu: „Obecny porządek jest nadprzyrodzony; od najwcześniejszej chwili, w której rozpoczyna się wszelkie ludzkie życie, zostają nam otwarte kanały łaski. Wszyscy rodzą się z człowieczeństwem, jakie przyjął sam Chrystus, i wszyscy w każdej chwili żyją w jakiejś relacji do Niego"80, bo od momentu stworzenia świata jest On w uprzedniej relacji do każdego człowieka, począwszy od Adama.

Mając na uwadze fakt, że każde działanie Boga w świecie od momentu stworzenia jest „w Chrystusie”, ,przez Niego” i „dla Niego”, czyli że każda udzielana w świecie ludziom łaska jest łaską Chrystusa, przejdźmy teraz do analizy dwóch tekstów z Listu do Rzymian, które - zdaniem ewangelikalnych inkluzywistów - potwierdzają tezę, że tzw. „ogólne objawienie” ma wymiar zbawczy, natomiast zdaniem ewangelikalnych ekskluzywistów stanowią jedynie podstawę do potępienia wszystkich. Jaka jest interpretacja tychże tekstów przez egzegetów i teologów katolickich?

18 Albowiem gniew Boży ujawnia się z nieba na wszelką bezbożność i nieprawość tych ludzi, którzy przez nieprawość nakładają prawdzie pęta. 19 To bowiem, co o Bogu można poznać, jawne jest wśród nich, gdyż Bóg im to ujawnił. 20 Albowiem od stworzenia świata niewidzialne Jego przymioty - wiekuista Jego potęga oraz bóstwo - stają się widzialne dla umysłu przez Jego dzieła, tak że nie mogą się wymówić od winy. 21 Ponieważ, choć Boga poznali, nie oddali Mu czci jako Bogu ani Mu nie dziękowali, lecz znikczemnieli w swoich myślach i zaćmione zostało bezrozumne ich serce. 22 Podając się za mądrych stali się głupimi. 23 I zamienili chwałęniezniszczalnego Boga na podobizny i obrazy śmiertelnego człowieka, ptaków, czworonożnych zwierząt i płazów. (Rz 1,18-23)

Jak zauważa Antoni Paciorek, chociaż w tym tekście „spojrzenie Apostoła kieruje się przede wszystkim ku ludziom żyjącym przed Chrystusem, to jednak jego wypowiedzi słusznie mogą odnosić się także do tych wszystkich, którzy

79 J. Bolewski, Biała Bogini, czarna Madonna... Maryjne światto w ezoterycznym odbiciu, Warszawa 2005, s. 298.

${ }^{80}$ Międzynarodowa Komisja Teologiczna, Nadzieja zbawienia dla dzieci zmarlych bez chrztu, dz. cyt., $\mathrm{nr} 95$. 
dzisiaj nie przyjmują Chrystusa"81. Odnośnie do przedmiotu poznania Paciorek zauważa, że chodzi o „te atrybuty Boga, które mogą być dostrzegane przez stworzenia. Mówią one o potędze Bożej, która powołuje do istnienia oraz o transcendencji, którą zdaje się wrażać termin «bóstwo»" ${ }^{2}$. Odnośnie do sposobu poznania, to „objawienie to dokonuje się przez świat stworzony oraz działalność umysłu" $"$.

Poznanie nie jest wynikiem objawienia pozytywnego lub pierwotnego. Dokonuje się poprzez rzeczy widzialne. Człowiek rozpoznaje je jako stworzone i ta ich właściwość prowadzi go do Stwórcy. Poznanie Boga nie jest poznaniem abstrakcyjnym, ale życiowym, poprzez które człowiek zwraca się do Boga jako swego celu i które pociaga za sobą obowiązek oddania czci Bogu. [...] Z całego kontekstu Rz 1,18n. wynika, że Apostoł uznaje w człowieku trwałą zdolność dojścia do poznania Boga, która jednak ze względu na pierwotne skażenie człowieka występuje obecnie w stanie znacznego osłabienia ${ }^{84}$.

Inny katolicki egzegeta, Joseph A. Fitzmyer, podkreśla, że w Rz 1,18-32 Paweł wydaje ocenę całej społeczności pogan ${ }^{85}$. Grzech pogan, o którym w tym fragmencie pisze Apostoł, polegał na tym, że nie poznali prawdziwego Boga i nie oddali $\mathrm{Mu}$ właściwej czci, jak powinni byli to uczynić ${ }^{86}$. Następnie egzegeta dodaje:

Należałoby zestawić to Pawłowe oświadczenie o wiedzy pogan o Bogu z tym, co Łukaszowy Paweł oświadcza w Dz 17,23: „Przechodząc bowiem i oglądając wasze świętości jedną po drugiej, znalazłem też ołtarz z napisem: «Nieznanemu Bogu». Ja wam głoszę to, co czcicie, nie znając”. Różnica jest uderzająca [...]. Cześć oddawana nieznanemu Bogu zakładałaby pewien rodzaj znajomości Boga, która domagałaby się oczyszczenia, poprawy i rozszerzenia, ale w Dziejach poganie nie są uznani jako ci, którzy nie mogą wymówić się od winy, jak pisze o tym Paweł w wierszu $20^{87}$.

Po czym, w komentarzu do tego stwierdzenia, autor cytuje następujące zdanie Vielhauera: „Oznacza to, że teologia naturalna posiada całkowicie inną funkcję w Rz 1 i w Dz 17; w pierwszym tekście funkcjonuje jako pomoc dla wykazania ludzkiej odpowiedzialności i jest zaraz potem porzucona; $w$ drugim tekście jest oceniona pozytywnie i użyta dla misyjnej pedagogii jako poprzedniczka wiary"88.

${ }^{81}$ A. Paciorek, «Poznanie Bogu» $i$ «prawo wpisane w sercu»-jaśniejsze strony egzegezy świata pogan wedtug Rz 1-2, w: Nowy Testament a religie, red. I.S. Ledwoń, Lublin 2011, s. 85.

${ }^{82}$ Tamże, s. 186.

${ }^{83}$ Tamże, s. 186-187.

${ }^{84}$ Tamże, s. 190.

${ }^{85}$ J.A. Fitzmyer, Romans. A New Translation with Introduction and Commentary, New York 1993, s. 270.

${ }^{86}$ Tamże, s. 281.

${ }^{87}$ Tamże, s. 281-282.

${ }^{88}$ Cyt. w: tamże, s. 282. 
Z powyższych analiz egzegetów można by zatem wyciągnąć następujący wniosek: wydaje się, że Rz 1,18-32 służy przede wszystkim dla potępienia tych, którzy byli beneficjentami objawienia przez stworzenia, bowiem je od razu odrzucili. W zestawieniu z Dz 17,23 można by natomiast argumentować, że nie wszyscy poganie i nie zawsze to objawienie przez stworzenia odrzucili. Podobny wniosek można wyciagnąć - jak to zobaczymy - przy interpretacji Rz 2,14-16.

W klasycznej teologii katolickiej objawienie się Boga przez świat stworzony, o którym jest mowa w Rz 1,18-23, nazywano „objawieniem naturalnym” w przeciwieństwie do „objawienia nadprzyrodzonego" mającego miejsce w historii Izraela i ostatecznie w Jezusie Chrystusie. Objawienie naturalne nie miało wymiaru zbawczego. Wielu współczesnych teologów katolickich kontestuje jednak takie rozróżnienie. W Polsce tacy teologowie jak Marian Rusecki i Ireneusz Sławomir Ledwoń podkreślają że objawienie się Boga przez stworzenia i w stworzeniach ma charakter chrystyczny i zbawczy, a wyrosłe na nim religie niechrześcijańskie zawierają się w zbawczej ekonomii Boga i historii zbawienia. Ledwoń stwierdza, że każdy rodzaj objawienia, a więc także to w stworzeniach i przez stworzenia, może stać się źródłem nadprzyrodzonego aktu wiary, dającej początek religijnej i zbawczej relacji człowieka z Bogiem ${ }^{89}$.

14 Bo gdy poganie, którzy Prawa nie mają, idąc za naturą, czynią to, co Prawo nakazuje, chociaż Prawa nie mają, sami dla siebie są Prawem. 15 Wykazują oni, że treść Prawa wypisana jest w ich sercach, gdy jednocześnie ich sumienie staje jako świadek, a mianowicie ich myśli na przemian ich oskarżające lub uniewinniające. 16 [Okaże się to] w dniu, w którym Bóg sądzić będzie przez Jezusa Chrystusa ukryte czyny ludzkie według mojej Ewangelii. (Rz 2,14-16)

W tekście tym Apostoł Narodów stwierdza, że poganie mają tę samą znajomość prawa co Izraelici, którzy przez Mojżesza otrzymali od Boga prawo spisane na kamiennych tablicach. Choć istnieje różnica między prawem Mojżeszowym a prawem napisanym w sercach ludzi (prawem naturalnym), to - jak zauważa Antoni Paciorek - pod względem treści nie ma między nimi zasadniczej różnicy. „Świadczy o tym przyznanie tego samego waloru czynom dokonanym zgodnie z Prawem Mojżeszowym oraz czynom dokonanym zgodnie z Prawem wypisanym w sercach" ${ }^{90}$. Poganie maja je wypisane w swoich sercach. Użyta metafora wskazuje na piszącego. Kto nim jest? W Drugim Liście do Koryntian św. Paweł mówi o Duchu Świętym. Zwraca się do chrześcijan w Koryncie w następujących słowach: „Wy jesteście naszym listem, pisanym w sercach naszych, listem, który znają i czytają wszyscy ludzie. Powszechnie o was wiado-

${ }^{89}$ I.S. Ledwoń, ,... i nie ma $w$ żadnym innym zbawienia”. Wyjątkowy charakter chrześcijaństwa w teologii posoborowej, Lublin 2006, s. 493.

90 A. Paciorek, «Poznanie Bogu» $i$ «prawo wpisane w sercu»-jaśniejsze strony egzegezy świata pogan wedlug Rz 1-2, dz. cyt., s. 192. 
mo, żeście listem Chrystusowym dzięki naszemu posługiwaniu, listem napisanym nie atramentem, lecz Duchem Boga żywego; nie na kamiennych tablicach, lecz na żywych tablicach serc" (2 Kor, 3,2-3). Można wnioskować, że także w przypadku pogan piszącym na tablicach ich serc jest ten sam Duch Święty. W Rz 8,5-11 św. Paweł wskazuje na kontrast między życiem „,według ciała” a życiem „według Ducha”. Ponownie tekst odnosi się do chrześcijan. Niemniej jednak skoro poganie także mogą żyć według Ducha, to również do nich można odnieść te słowa:

Ci bowiem, którzy żyją według ciała, dążą do tego, czego chce ciało; ci zaś, którzy żyją według Ducha - do tego, czego chce Duch. Dążność bowiem ciała prowadzi do śmierci, dążność zaś Ducha - do życia i pokoju. A to dlatego, że dążność ciała wroga jest Bogu, nie podporządkowuje się bowiem Prawu Bożemu, ani nawet nie jest do tego zdolna. A ci, którzy żyją według ciała, Bogu podobać się nie mogą. Wy jednak nie żyjecie według ciała, lecz według Ducha, jeśli tylko Duch Boży w was mieszka (Rz 8,5-9).

Podobnie w innych tekstach, jak chociażby w Ga 4,6: „Na dowód tego, że jesteście synami, Bóg wysłał do serc naszych Ducha Syna swego, który woła: Abba, Ojcze!". Wcześniej, w wersetach 4-5 mowa jest o zesłaniu Syna. Mamy zatem misje Syna i Ducha Świętego. Choć możemy je rozróżniać, nie powinno się jednak ich oddzielać. Oczywiście, nauczanie św. Pawła skierowane jest do chrześcijan. Niemniej jednak, jak słusznie zauważa Gerald O'Collins, skoro jest w nim mowa o działaniu Ducha Świętego w sercach ludzkich, można rozszerzyć to działanie także na wszystkich ludzi, podkreślając jego powszechny zasięg ${ }^{91}$. „To, co Paweł stwierdza odnośnie do zesłania Ducha Świętego do «serc» wierzących chrześcijan, może być słusznie odniesione do pewnego rodzaju zesłania Ducha do serc tych jeszcze niezewangelizowanych i nieochrzczonych" ${ }^{92}$. Dlatego w Konstytucji dogmatycznej o Kościele mamy zdanie: „Nie odmawia też Opatrzność Boża koniecznej do zbawienia pomocy takim, którzy bez własnej winy w ogóle nie doszli jeszcze do wyraźnego poznania Boga, a usiłują, nie bez łaski Bożej, wieść uczciwe życie"93 (KK 16; podkreślenia nasze - Z.K.).

Bez wiary zaś nie można podobać się Bogu. Przystępujący bowiem do Boga musi wierzyć, że [Bóg] jest i że wynagradza tych, którzy Go szukają. (Hbr 11,6)

Tekst ten jest w pewnym sensie podsumowaniem wcześniejszych wersetów (Hbr 11,1-5), gdzie wiara zdefiniowana jest jako „poręka tych dóbr, których się spodziewany, dowodem tych rzeczywistości, których nie widzimy" (Hbr 11,1),

\footnotetext{
${ }^{91}$ G. O'Collins, Salvation for All. God's Other Peoples, Oxford 2008, s. 137.

92 Tamże, s. 138.

${ }^{93}$ Sobór Watykański II, Konstytucja dogmatyczna o Kościele Lumen gentium, w: Sobór Watykański II. Konstytucje, Dekrety, Deklaracje, dz. cyt., nr 16 [podkreślenie nasze - Z.K.].
} 
po czym autor listu mówi o wierze Abla i Henocha. Wiara Abla wyrażona została w ofierze, jaką Bogu złożył z pierwocin. Drugim przykładem jest Henoch, o którym Biblia powiada, że „kroczył przed Bogiem, a następnie znikł, bo zabrał go Bóg" (Rdz 5,24). Werset 6, stwierdzający, że bez wiary nie można podobać się Bogu, stanowi swego rodzaju podsumowanie. Oznacza to, że Abel i Henoch podobali się Bogu, bo mieli wiarę. Dalej w Hbr 11,6b wskazuje się na dwa istotne elementy, jakie taka wiara zawiera: że „Bóg jest i że wynagradza tych, którzy Go szukają". Jak pisze w swoim komentarzu Piotr Kasiłowski:

Autorowi nie chodzi o polemikę z ateizmem, czy o rozróżnienie między istotą i istnieniem Boga (por. Mdr 13,1), gdyż mówi o wierze ,człowieka zbliżającego się (proserchomenon) do Boga”. Obraz „zbliżania się” w Hbr często służy na określenie „oddawania czci”, „sprawowania kultu”. Mowa jest o dwóch warunkach: konieczną jest rzeczą (dei) wierzyć, że „Bóg jest”, i że „nagradza szukających Go”. Nie mówi się tu o wszystkich elementach wiary potrzebnej do zbawienia. Nie ma tu np. odniesienia chrystologicznego, podobnie jak w 6,1 przy wymienianiu składników ,elementarnego pouczenia" autor nie mówi explicite o Chrystusie ${ }^{94}$.

Komentujący ten sam tekst australijski teolog, Gerald O'Collins, zauważa, że jego przesłanie jest jednoznaczne:

Bez odpowiedzi wiara na objawienie przekazane przez Syna Bożego i Ducha Świętego nikt nie może „podobać się Bogu” i otrzymać zbawienia. Ujmując to pozytywnie, można powiedzieć, że udzielony każdemu dar światła i życia czyni możliwym, odpowiednio, wiarę i zbawienie. Chrystus podejmuje inicjatywę jednocześnie jako powszechny Objawiciel i powszechny Zbawiciel. Boże poszukiwanie wszystkich istot ludzkich, a nie ludzkie poszukiwanie Boga, powinno stanowić całkowitą podstawę dla każdej koncepcji nie tylko zbawienia, ale i objawienia ${ }^{95}$.

Na podstawie oświadczeń znajdujących się w innych miejscach Listu do Hebrajczyków O'Collins wskazuje na pięć elementów wiary, o której jest mowa w Hbr 11,6. Zauważa przede wszystkim, że obecne w następnych rozdziałach listu napomnienia wskazują, co „podobanie się Bogu” za sobą pociąga. Przytacza po kolei cytaty z Hbr 12,28, 13,16 i 13,20-12, by skonkludować, że to, co podoba się Bogu, to jest wiara, która oddaje Bogu cześć i wypełnia Jego wolę przez czyny dobra oraz służby wobec innych.

Najwyraźniej wiara explicite w Chrystusa - pisze - żywotnie wzmocni życie wiary. Wertykalna relacja z Bogiem (poprzez kult dziękczynienia) i horyzontalna relacja z innymi ludźmi (poprzez życzliwą samoofiarę) domaga się niewidzialnego wsparcia Ducha Świętego, ale jako taka nie zależy od świadomej relacji z Chrystusem. Wiara, która jest Bogu miła, jest możliwością otwartą dla wszystkich ${ }^{96}$.

\footnotetext{
${ }_{94}$ P. Kasiłowski, Pochwała wiary (Hbr 11), „Bobolanum” 10(2), 1999, s. 300.

${ }^{95}$ G. O'Collins, Salvation for All, dz. cyt., s. 251.

${ }^{96}$ Tamże, s. 255.
} 
Oznacza to, że wiara, jaka podoba się Bogu, niekoniecznie musi być wiarą explicite w Chrystusa. Jak zauważa O'Collins, przybliżanie się do Boga przez wiarę i kult przez niechrześcijan nie musi oznaczać świadomości, że takie „przybliżanie się" zależy od kapłańskiego pośrednictwa zmartwychwstałego Chrystusa ${ }^{97}$.

W tym miejscu warto jeszcze przytoczyć wypowiedź ks. Mariana Sieniatyckiego, profesora Uniwersytetu Jagiellońskiego, który pisząc w 1930 r. na temat zbawienia przez wiarę niechrześcijan (on sam używa słowa „niewiernych”) stwierdza:

Przedmiotem tej wiary, którą wyraźnie (fide explicita) i koniecznie (necessitate medii) trzeba wierzyć, jest, jak Apostoł mówi, istnienie Boga i jego Opatrzność nad ludźmi objawiająca się przede wszystkim w sprawiedliwych nagrodach i karach. Otóż nasuwa się kwestia, w jaki sposób wiara w te dwie prawdy przez objawienie może być przez niewiernych nabyta? Sposoby Opatrzności Bożej mogą być dla różnych osób rozmaite. Teologowie wyliczają następujące: a) Do jednych posyła Bóg misjonarza, którego zjawienie się u nich bywa nieraz jakby cudowne, w każdym razie dziwne. b) Innych poucza Bóg o wspomnianych dwóch prawdach przez wewnętrzne oświecenie. c) Do bardzo wielu niewiernych mogły te dwie prawdy dostać się z pierwotnego objawienia przez pierwszych rodziców i pierwsze ludzkie pokolenia otrzymanego, które tradycją przeszło do dalszych pokoleń i utrzymało się po dziś dzień między niewiernymi. Tem łatwiej można to przyjąć, że te dwie prawdy łatwo i samym rozumem mogą być poznane, wskutek czego ułatwionem było zachowanie ich przez tradycję ${ }^{98}$.

Mamy tu wyraźną aluzję do Hbr 11,6. W innym miejscu Sieniatycki tłumaczy, dlaczego wiara w te dwie prawdy, tzn. w istnienie Boga i w opatrzność Bożą, jest wystarczająca do zbawienia. Znowu warto przytoczyć dłuższy passus z jego traktatu, gdzie ponownie znajdujemy odniesienie do Hbr 11,6. Oto uzasadnienie:

Odpowiednią było rzecza, żeby wiara wyraźna $\mathrm{w}$ te dwie prawdy była konieczną do zbawienia: a) Kto wyraźnie wierzy w Boga, tem samem wierzy implicite w przymioty Boże, w Trójcę św., w ogóle w Boga, jakim jest sam w sobie. Kto znów wierzy w Opatrzność Boża, ten implicite wierzy, iż Pan Bóg daje środki człowiekowi potrzebne do zbawienia, a więc wierzy we wcielenie, w łaskę, w nieśmiertelność duszy itd. b) Konieczną jest rzecza, by człowiek znał te dwie prawdy przez wiarę explicite, gdyż inaczej nie znałby celu ostatecznego, do którego ma dążyć, nie mógłby obudzić w sobie nadziei, która jest potrzebna do usprawiedliwienia, ani miłości, która, poza sakramentem, jest jedyną najbliższą dyspozycją do usprawiedliwienia $(\mathrm{Hbr} 11,6)^{99}$.

\footnotetext{
${ }^{97}$ G. O'Collins, Salvation for All, dz. cyt., s. 255.

${ }^{98}$ M. Sieniatycki, Zarys dogmatyki katolickiej, t. 3: O łasce i cnotach wlanych, Kraków 1930,

${ }^{99}$ Tamże, s. 262-263.
} s. 98. 
$* * *$

Podsumowując całość przedstawionych tu analiz i rozważań, należy stwierdzić, że we współczesnym chrześcijaństwie opcja eksklyzywistyczna najbardziej zakorzeniona jest $\mathrm{w}$ środowiskach ewangelikalnych. Wynika to przede wszystkim z ich szczególnego podejścia do interpretacji Pisma Świętego. Konfrontacja z tą interpretacją pokazuje, że choć Pismo Święte jest „normą normującą" dla całej doktryny chrześcijańskiej i jej przepowiadania, niemniej jednak jego przyjęcie jako słowa Bożego oraz jego interpretacja zawsze dokonuje się we wspólnocie Kościoła. Widać to chociażby na przykładzie kształtowania się kanonu Pisma Świętego. Wiemy, że w I wieku i znacznej części I połowy II wieku termin Pismo Święte oznacza dla chrześcijan księgi Starego Testamentu. Chrześcijanie przyjęli jako kanoniczne księgi Starego Testamentu w wersji Septuaginty. Kanon Nowego Testamentu ukonstytuował się w podobny sposób do pism Starego Testamentu, tzn. progresywnie: najpierw przyjęto listy Pawła, następnie Ewangelie. W połowie II wieku zaczęto już uważać te teksty za kanoniczne. Niemniej jednak, obok tych tekstów istniały w obiegu inne, które nazywano „apokryfami”. Kanon Starego Testamentu (w wersji LXX) i Nowego Testamentu ostatecznie został ukonstytuowany w IV wieku na soborze w Kartaginie w 397 r. Do tego czasu niektóre pisma najpierw funkcjonowały jako kanoniczne, ale ostatecznie za takie nie zostały przez Kościół uznane. W kontekście kontrowersji z protestantami Sobór Trydencki ponownie ustalił listę ksiąg kanonicznych Pisma Świętego Starego i Nowego Testamentu. Przyjął w całości listę ksiąg Pisma Świętego, jaką wyłożył już wcześniej Sobór we Florencji. Dyskusja z luteranami dotyczyła tzw. ksiąg deuterokanonicznych, tzn. ksiąg, których nie ma w Biblii hebrajskiej, a znajdują się w Septuagincie. W tej krótkiej historii kształtowania się kanonu istotny jest stosunek między Pismem Świętym a Kościołem. Biblia bowiem sama z siebie nie ustanowiła kanonu. Uczynił to Kościół. Jak zauważa Bernard Sesboüé, w kształtowaniu się kanonu Pisma Świętego istnieje dziwny paradoks: akt poddania się Kościoła autorytetowi Pisma Świętego i jego pokory wobec Pisma Świętego jest jednocześnie aktem ustanowienia kanonu Pisma Świętego ${ }^{100}$. Z jednej strony bowiem Kościół jest przede wszystkim podmiotem, który w duchu posłuszeństwa przyjmuje Pismo Święte, które już istnieje jako wynik opatrzności Bożej. Jednocześnie, z drugiej strony, to Kościół autoryzuje kanon Pisma Świętego, gdyż Pismo Święte jako takie nie ma w sobie mocy autoryzowania się. Jedynie wspólnota wiary może powiedzieć, że wierzy, iż Bóg natchnął dane święte księgi. Ta wzajemna zależność między wspólnotą Kościoła a Pismem Świętym jest widoczna także przy interpretacji Pisma Świętego.

${ }^{100}$ B. Sesboüé, Essai de théologie systématique sur le canon des Ecritures, w: Le canon des Écritures. Études historiques, exégétiques et systématiques, Paris 1990, s. 527. 
Jak czytamy w dokumencie Papieskiej Komisji Biblijnej pt. Interpretacja Biblii w Kościele, egzegezę katolicką ,charakteryzuje [...] to, że świadomie sytuuje się w żywej tradycji Kocioła, którego pierwszą troską jest wierność Objawieniu poświadczonemu przez Biblię"101. Innymi słowy, nie da się czytać i interpretować Pisma Świętego w oderwaniu od tradycji Kościoła. Na swój sposób potwierdzają to także teologowie ewangelikalni opcji ekskluzywistycznej. Często odwołują się do protestanckiej zasady sola Scriptura. Niemniej jednak, swoją krytykę interpretacji niektórych fragmentów Pisma Świętego przez teologów ewangelikalnych opcji inkluzywistycznej thumaczą tym, że proponowana przez nich interpretacja nie wpisuje się w nurt tradycji ewangelikalnej ${ }^{102}$. Potwierdza to zasadę, że interpretacja Pisma Świętego dokonuje się zaw s ze wewnątrz i w relacji do (jakiejś) tradycji Kościoła. Jak czytamy we wspomnianym wyżej dokumencie Papieskiej Komisji Biblijnej: „Biblia sama jest od początku interpretacją" ${ }^{103}$. Stąd w jednym z wniosków dotyczących interpretacji tekstów biblijnych czytamy: „Zważywszy, że teksty Pisma Świętego czasami pozostają w pewnym napięciu, interpretacja z konieczności winna być pluralistyczna. Żadna cząstkowa interpretacja nie może być interpretacją całości, która jest wielogłosową symfonią. Interpretacja pojedynczego tekstu powinna więc unikać ekskluzywizmu"104. Odnosząc to do naszych rozważań o zbawieniu niechrześcijan, nie da się na podstawie Rz 1,18-32 kategorycznie udowodnić, że Biblia odrzuca opcję inkluzywistyczną w teologii religii. Na poparcie tej opcji zacytować możemy przedstawioną wyżej interpretację takich tekstów jak Kol 1,15-20, Dz 17,3, Rz 2,14-16, oraz w pewnym (zawężonym) stopniu Hbr 11,6, oraz wiele innych tekstów biblijnych ze Starego i Nowego Testamentu ${ }^{105}$.

Ponadto, w tradycji katolickiej podkreśla się, że w misji właściwej interpretacji słowa Bożego zawartego w Piśmie Świętym i przekazanego przez Tradycję w sposób szczególny uczestniczy Nauczycielski Urząd Kościoła, jak czytamy w Konstytucji dogmatycznej o Kościele:

Zadanie [...] autentycznej interpretacji słowa Bożego, spisanego czy przekazanego przez Tradycję, powierzone zostało samemu tylko żywemu Urzędowi Nauczycielskiemu Kościoła, który autorytatywnie działa w imieniu Jezusa Chrystusa. Urząd ten

\footnotetext{
${ }^{101}$ Papieska Komisja Biblijna, Interpretacja Biblii w Kościele. Dokument Papieskiej Komisji Biblijnej z komentarzem biblistów polskich, przekład i redakcja Ryszard Rubinkiewicz, Warszawa 1999, s. 66.

${ }^{102}$ Tak np. S.J. Wellum, odnosząc się do inkluzywistycznej interpretacji Rz 1,18-32 przez Tiessena, oświadcza: „W tym punkcie Tiessen odrzuca standardową ewangelikalną interpretację Rz 1,18-32, mianowicie, że ogólne objawienie nie jest zbawcze" - Saving Faith. Implicit or Explicit?, dz. cyt., s. 157.

${ }^{103}$ Papieska Komisja Biblijna, Interpretacja Biblii w Kościele, dz. cyt., s. 71.

104 Tamże, s. 71.

${ }^{105}$ Więcej na ten temat w mojej książce Kościót, religie i zbawienie. O jedyności i powszechności zbawczej Kościoła oraz zbawczej roli religii niechrześcijańskich, Kraków 2016, s. 542-573.
} 
Nauczycielski nie jest ponad słowem Bożym, lecz jemu służy, nauczając tylko tego, co zostało przekazane. Z rozkazu Bożego i przy pomocy Ducha Świętego słucha on pobożnie słowa Bożego, święcie go strzeże i wiernie wyjaśnia. I wszystko, co podaje do wierzenia jako objawione przez Boga, czerpie z tego jednego depozytu wiary. Jasne więc jest, że Święta Tradycja, Pismo św. i Urząd Nauczycielski Kościoła, wedle najmądrzejszego postanowienia Bożego, tak ściśle ze sobą się łączą i zespalają, że jedno bez pozostałych nie może istnieć, a wszystkie te czynniki razem, każdy na swój sposób, pod natchnieniem jednego Ducha Świętego przyczyniają się skutecznie do zbawienia dusz ${ }^{106}$.

W 2011 roku opublikowana została książka pt. Only One Way? Three Christian Responses on the Uniqueness of Christ in a Religously Plural World (Czy tylko jedna droga? Trzy odpowiedzi chrześcijan na temat jedyności Chrystusa $w$ pluralistycznym religijnie świecie $)^{107}$. Zawiera ona trzy artykuły trzech teologów chrześcijańskich, a następnie prowadzoną między nimi dyskusję: Paula Knittera, który jest katolikiem i zwolennikiem opcji pluralistycznej, Gavina D’Costy, który jest katolikiem i zwolennikiem opcji inkluzywistyczej, oraz Daniela Strange'a, który jest reformowanym ewangelikalnym protestantem i zwolennikiem opcji ekskluzywistycznej. W tym miejscu pragnę jedynie zacytować jedno zdanie z odpowiedzi, jaką Strange kieruje pod adresem tekstu D'Costy, który jako teolog katolicki w uzasadnieniu swojej pozycji inkluzywistycznej często odwołuje się do najnowszego nauczania Magisterium Kościoła katolickiego. Strange pisze:

jako reformowany ewangelikalny protestant muszę ostatecznie odrzucić zarówno metodę, jak i argumentację [D'Costy], gdyż jego pozycja zbudowana jest na podstawowym fundamencie bardzo różnym od mojej tradycji. Twierdziłbym, że te fundamenty są bardzo słabe, ponieważ podważaja ,solismy” Reformacji (sola Scriptura, solus Christus, sola gratia, soli Deo Gloria i sola fide $)^{108}$.

Nie miejsce tu na wchodzenie w dyskusję z tym stwierdzeniem Strange'a i jego krytyką katolickiej opcji inkluzywistycznej. Uczynił to sam D'Costa ${ }^{109}$. Chcę jedynie zauważyć, że tradycja, z której się wywodzimy i z którą się utożsamiamy, warunkuje naszą interpretację Pisma Świętego. Stąd potrzeba i wartość dialogu ekumenicznego. Studium teologii religii w ujęciu ewangelikalnych teologów opcji ekskluzywistycznej pokazuje jedno: każda chrześcijańska teologia powinna opierać się na objawieniu poświadczonym przez Biblię. Niemniej jednak jej interpretacja dokonuje się w żywej tradycji Kościoła. Dla mnie jest to tradycja Kościoła katolickiego.

${ }^{106}$ Sobór Watykański II, Konstytucja dogmatyczna o Objawieniu Bożym Dei Verbum, w: Sobór Watykański II. Konstytucje, Dekrety, Deklaracje, dz. cyt., nr 10.

${ }^{107}$ G. D'Costa, P. Knitter, D. Strange, Only One Way? Three Christian Responses on the Uniqueness of Christ in a Religously Plural World, London 2011.

108 Tamże, s. 175.

109 Tamże, s. 185-193. 
W konstytucji Lumen gentium mowa jest o kręgach przyporządkowania do Kościoła. Ostatni stanowią ci, którzy jeszcze w Boga nie wierzą ale są ludźmi dobrymi i żyją uczciwie. Czytamy:

Nie odmawia też Opatrzność Boża koniecznej do zbawienia pomocy takim, którzy bez własnej winy w ogóle nie doszli jeszcze do wyraźnego poznania Boga, a usiłuja nie bez laski Bożej, wieść uczciwe życie. Cokolwiek bowiem znajduje się w nich z dobra i prawdy, Kościół traktuje jako przygotowanie do Ewangelii i jako dane im przez Tego, który każdego człowieka oświeca, aby ostatecznie posiadł życie ${ }^{110}$.

Jeśli tacy ludzie osiaggną zbawienie, to nie mocą własnych uczynków, ale mocą łaski Bożej, co w cytowanym tekście jest wyraźnie powiedziane. Takie uczciwe życie oparte na łasce Bożej jest ich aktem wiary implicite w Chrystusa. Można powiedzieć, że są , anonimowymi chrześcijanami”. Podstawę biblijną takiej interpretacji stanowi przypowieść Jezusa o sądzie ostatecznym zapisana w Ewangelii Mateusza (Mt 25,31-46), która mówi, że wszyscy będą sądzeni na podstawie czynów miłości wobec potrzebujących. Nie jest to podważenie ani jedyności i powszechności zbawczej Jezusa Chrystusa, ani konieczności misji Kościoła. Tacy ludzie pozbawieni są bowiem pełni środków zbawienia. Pozbawieni są także możliwości świadomego i pełnego uwielbienia Boga. Stąd konieczność głoszenia im Ewangelii Jezusa Chrystusa. Niemniej jednak, nie mając wiary w Chrystusa o charakterze explicite, mogą osiagnąc zbawienie. Choć uważam - podobnie jak Tiessen i D'Costa - że tacy ludzie w momencie śmierci będą musieli przejść przez proces oczyszczenia i dopełnienia $\mathrm{z}$ wiary implicite do wiary explicite w Jezusa Chrystusa, jedynego Pana i Zbawiciela ${ }^{111}$.

\section{Evangelical Exclusivism}

\section{Summary}

Within the Christian theology of religions one distinguishes three basic paradigms: exclusivism, inclusivism and pluralism. Pluralism considers all religions as equal ways of salvation leading to God. It denies that Jesus Christ is the unique Savior of the world. Inclusivism maintains the unicity and salvivic universality of Jesus Christ, but affirms that explicit faith in Jesus Christ is not necessary for salvation for unevangelized people. Exclusivism is the view that Jesus Christ is the only Savior of the world and that one must believe God's special revelation that culminates in the gospel of Christ in order to be saved. Evangelical theologians principally maintain this position. Interestingly enough, on the one hand they affirm that children who die in infancy (as well as people who are mentally incompetent) are included within the circle of God's saving grace and will be saved; on the other hand, they say that since the first coming of Christ the only way of salvation is explicit faith in him.

${ }^{110}$ Sobór Watykański II, Konstytucja dogmatyczna o Kościele Lumen gentium, dz. cyt., nr 16.

${ }^{111}$ Więcej na ten temat, zwłaszcza gdy chodzi o stanowisko Gavina D’Costy, które przyjmuję, w mojej książce Kościót, religie i zbawienie, s. 486-487. 
The article is divided into three parts. The first part examines the argument of those theologians about the fate of children who die in infancy and then compares it with the teaching of the Catholic Church expressed by the International Theological Commission in its document The Hope of Salvation for Infants Who Die Without Being Baptized (2007). The second part examines the biblical and theological arguments advanced by evangelical theologians in favor of exclusivism. In the third part these arguments are discussed from the perspective of Catholic theology. For Catholics as much as for evangelicals, there is no doubt that Jesus Christ is the unique Savior of the world and that salvation has always been by grace through faith. The difference concerns the content of this saving faith. Must it have as its object an explicit knowledge of Jesus Christ, as is argued by the evangelical exclusivists?

\section{Keywords}

exclusivism, inclusivism, evangelical theology, theology of religions, salvation

\section{Słowa kluczowe}

ekskluzywizm, inkluzywizm, teologia ewangelikalna, teologia religii, zbawienie

\section{Bibliografia}

Aletti J.N., Saint Paul - Epitre aux Colossiens. Introduction, traduction, commentaire, Paris 1993.

Boismoard M.E., A l'aube du christianisme. Avant la naissance des dogmes, Paris 1998.

Bolewski J., Biała Bogini, czarna Madonna... Maryjne światło w ezoterycznym odbiciu, Warszawa 2005.

Capéran L., Le problème du salut des infidèles, t. 1: Essai historique, Paris 1912.

D'Costa G., Knitter P., Strange D., Only One Way? Three Christian Responses on the Uniqueness of Christ in a Religously Plural World, London 2011.

Fitzmyer J.A., Romans. A New Translation with Introduction and Commentary, New York 1993.

Kaiser Jr. W.C., Holy Pagans. Reality or Myth?, w: Faith Comes by Hearing. A Response to Inclusivisme, red. Ch.W. Morgan, R.A. Peterson, Downers Grove [USA, Illinois] 2008, s. 123-141.

Kasiłowski P., Pochwała wiary (Hbr 11), „Bobolanum” R. 10(2), 1999, s. 291-324.

Kubacki Z., Kościól, religie i zbawienie. O jedyności i powszechności zbawczej Kościoła oraz zbawczej roli religii niechrześcijańskich, Kraków 2016.

Ledwoń I.S., ,„... i nie ma $w$ żadnym innym zbawienia”. Wyjatkowy charakter chrześcijaństwa w teologii posoborowej, Lublin 2006.

Matera F.J., New Testament Christology, Luisville [USA, Kentucky] 1999.

Międzynarodowa Komisja Teologiczna, Nadzieja zbawienia dla dzieci zmartych bez chrztu. Dokument watykański, Radom 2008.

Moingt J., Dieu qui vient à l'homme, t. 2: De l'apparition à la naissance de Dieu, 1: Apparition, Paris 2005. 
Morgan Ch.W., Peterson R.A., Answers to Notable Questions, w: Faith Comes by Hearing. A Response to Inclusivisme, red. Ch.W. Morgan, R.A. Peterson, Downers Grove [USA, Illinois] 2008, s. 241-255.

Nash R.H., When a Baby Dies. Answers to Comfort grieving Parents, Michigan 1999.

Nash R.H., Restrictivism, w: What About Those Who Have Never Heard? Three Views on the Destiniy of the Unevangelized, red. J. Sanders, Downers Grove [USA, Illinois] 1995, s. 107-140.

O'Collins G., Salvation for All. God's Other Peoples, Oxford 2008.

Paciorek A., «Poznanie Bogu» $i$ «prawo wpisane w sercu»-jaśniejsze strony egzegezy świata pogan wedlug Rz 1-2, w: Nowy Testament a religie, red. I.S. Ledwoń, Lublin 2011, s. 185-199.

Papieska Komisja Biblijna, Interpretacja Biblii w Kościele. Dokument Papieskiej Komisji Biblijnej z komentarzem biblistów polskich, przekład i redakcja R. Rubinkiewicz, Warszawa 1999.

Peterson R.A., Inclusivism versus Exclusivism on Key Biblical Textes, w: Faith Comes by Hearing. A Response to Inclusivisme, red. Ch.W. Morgan, R.A. Peterson, Downers Grove [USA, Illinois] 2008, s. 184-200.

Pinnock C.H., The Flame of Love: A Theology of the Holy Spirit, Downers Grove [USA, Illinois] 1996.

Sesboüé B., Essai de théologie systématique sur le canon des Écritures, w: Le canon des Écritures. Études historiques, exégétiques et systématiques, Paris 1990, s. 523-540.

Sieniatycki M., Zarys dogmatyki katolickiej, t. 3: O łasce i cnotach wlanych, Kraków 1930.

Sobór Watykański II, Konstytucja dogmatyczna o Objawieniu Bożym „Dei Verbum”, w: Sobór Watykański II. Konstytucje, Dekrety, Deklaracje. Tekst łacińsko-polski, Paris 1967, s. 337-357.

Sobór Watykański II, Konstytucja dogmatyczna o Kościele „Lumen gentium”, w: Sobór Watykański II. Konstytucje, Dekrety, Deklaracje. Tekst łacińsko-polski, Paris 1967, s. 77-175.

Sobór Watykański II, Konstytucja duszpasterska o Kościele w świecie współczesnym „Gaudium et spes”, w: Sobór Watykański II. Konstytucje, Dekrety, Deklaracje. Tekst łacińsko-polski, Paris 1967, s. 533-657.

Strange D., General Revelation. Sufficient or Insufficient?, w: Faith Comes by Hearing. A Response to Inclusivisme, red. Ch.W. Morgan, R.A. Peterson, Downers Grove [USA, Illinois]: InterVarsity Press, 2008, s. 40-77.

Tiessen T.L., Who Can Be Saved? Reassessing Salvation in Christ and World Religions, Downers Grove [USA, Illinois] 2004.

Tomasz z Akwinu, Suma teologiczna, Londyn 1973-1998.

Webb R.A., The Theology of Infant Salvation, Richmond, VA 1907.

Wellum S.J., Saving Faith. Implicit or Explicit?, w: Faith Comes by Hearing. A Response to Inclusivisme, red. Ch.W. Morgan, R.A. Peterson, Downers Grove [USA, Illinois] 2008, s. 142-183. 